\title{
EFFECT OF NITROGEN FERTILIZER AND COMPOST RATES ADDITION AT DIFFERENT DEPTHS ON SOME SOIL CHEMICAL PROPERTIES
}

\author{
El-Maddah E.I., El-Sodany M.El-D. and Abd-Allah Y.A.M.
}

Soil, Water and Environment Research Inst. Agric. Res. Center, Giza, Egypt

*Corresponding author: $\underline{\mathrm{dr} \text { yosri@hotmail.com }}$

\section{ABSTRACT}

Two field experiments were conducted on clay loam soil during the two successive seasons, summer season 2017 using maize plants and winter season 2017/2018 using barley plants at ElGemmeiza Agricultural Research Station, ElGharbia Governorate to evaluate the direct and residual effects of compost rates mixed with the surface soil layer to $10 \mathrm{~cm}$ or added in $30 \mathrm{~cm}$ mole depth, arranged in parallel orientation with respect to one another and spaced at $3 \mathrm{~m}$ apart besides the nitrogen fertilizer rates on improving some soil chemical properties. Furthermore economical analysis was done by calculating the net income for every treatment to determine the economical treatment.

The rates of compost were $0.0,2.5,5.0$ and 7.5 Ton fed-1, while the nitrogen rates were $0.0,50,75$ and $100 \%$ of the recommended dose for every growing crop. The experiments were conducted in a split-split plot in a randomized complete block design (RCBD) with three replicates.

All treatments slightly decreased the soil reaction $(\mathrm{pH})$ in the two growing seasons. Soil salinity (EC), soluble cations and anions and total soluble salts (TSS) significantly increased by increasing nitrogen or compost rates and significantly decreased by increasing application depth. On the other hand, SAR values were significantly decreased with all treatments. All treatments led to significant increases in $\mathrm{Ex}$. $\mathrm{Ca}, \mathrm{Mg}, \mathrm{K}$ and cation exchange capacity (CEC), whereas Ex. $\mathrm{Na}$ and ESP were significantly decreased with all treatments in the two seasons. All treatments clearly enhanced total nutrients (N. P and $\mathrm{K}$ ) of the investigated soil. Also, Organic carbon (O.C, \%) and $\mathrm{C} / \mathrm{N}$ ratio were significantly increased with all treatments. According to the economical analysis,
\end{abstract}

the application of 5 ton compost fed-1 in $30 \mathrm{~cm}$ mole depth with $100 \%$ the recommended dose of nitrogen fertilizer for every crop was the best treatment compared with the other treatments and get a markedly improve in chemical properties which reflect on higher yield, since it gave the highest net income (16809.80 L.E fed-1).

Keywords: Moles, Compost, Soil chemical properties

\section{INTRODUCTION}

In the Middle Delta, at El-Gemmeiza Agricultural Research Station, the reduction in crop yields could possibly be ascribed to the soil compaction that can be induced by agro mechanical operations for long periods, El-Maddah and El-Sodany (2003). Also, they reported that the moles at 2, 4 and $6 \mathrm{~m}$ spacing in 30 and $60 \mathrm{~cm}$ depth clearly increased leaching the soluble salts and decreased EC and SAR values. Also, the crossed moles were better during the two seasons since they decreased EC, SAR and total soluble salts as compared with the achieved by parallel ones.

Improving the heavy clay compacted soils can be achived by drainage and sub-soiling technique. Mole drains are conveniently used in heavy soils. If no changes in management practices were made after mole drains the study soil were re-compacted within 3 years with the same or worse physical chemical properties and land qualities. The zones broken channels should be too narrow to prevent the re-compacted in a few years. On the other hand, drainage installation for leaching purpose will only be fully successful if they permit the uniform leaching of soluble salts from the whole soil profile. 
El-Sabry et al (1992) found that the superiority of treatment was $3 \mathrm{~m}$ spacing compared with the other treatments (6, 8 and $12 \mathrm{~m}$ spacing). Furthermore all treatments increased leaching of soluble salts and decreased SAR values comparing with the control (without moling).

Abou El-Soud et al (1996) reported that the data obtained in all seasons under their study that installation of moles at 2, 4 and $6 \mathrm{~m}$ spacing decreased ECe values by $40.5,41.1$ and $33.0 \%$ respectively comparing to the control. The crossed moles were better during all seasons since they decreased ECe by about $8.0 \%$ as compared with that achieved by the parallel ones.

El-Sodany et al (2016) found that the use of compost rates at different depths in moles (20 and $40 \mathrm{~cm}$ ) get a markedly improve in chemical properties which reflect on higher yield incorporated with high net income. Also, soil reaction $(\mathrm{pH})$, SAR values were decreased by the addition of compost rates at different depths. While soil salinity (EC) and total soluble salts (TSS), soluble cations and anions, Organic carbon (O.C, \%) and $\mathrm{C} / \mathrm{N}$ ratio were increased.

Moreover, most of the cultivated soils in our country have organic matter far way below a good agricultural soil that should contain at least $2 \%$ organic matter. So, when compost is applied to the soil, it can support plant growth and enhance plant yield as well as improve the physical, chemical and biological properties of soils (Convertini et al 2004).

Eghball et al (2004) found that the residual effects of manure and compost applications significantly increased soil electrical conductivity and $\mathrm{pH}$ levels. Saraiya et al (2005) showed that the application of compost prepared from rice residue to wheat increased organic carbon content. El-hady and Abo-Sedera (2006) reported that the soil conditioning positively effect chemical and biological properties of the soil these effects are assembled in the following: (a) slightly decreasing soil $\mathrm{pH}$, (b) increasing both CEC of the soil and its specific surface area indicating an improvement in activating chemical reactions in the soil, (c) increasing OM, organic carbon, total nitrogen $\%$ in the soil, Because the increase in total nitrogen is higher than that in organic carbon, narrower $\mathrm{C} / \mathrm{N}$ ratio of treated soils were obtained indicating the mineralization of organic nitrogen compounds and hence the possibility to save and provide available forms of $\mathrm{N}$ to growing plants, (d) increasing $\mathrm{N}, \mathrm{P}$ and $\mathrm{K}$ in treated soil.
El-Maddah et al (2012) found that all soil conditioners slightly decreased the soil reaction $(\mathrm{pH})$, Ex. Na and ESP and increase soil salinity, Ex. Ca, $\mathrm{Mg}$ and cation exchange capacity (CEC), Organic carbon (O.C, \%), C/N ratio, available NPK and soil extractable metals (Fe, $\mathrm{Zn}, \mathrm{Mn}$ and $\mathrm{Cu}$ ). Also, ElSodany and El-Maddah (2009) reported that the use of organic matter lead to a slightly decreases in soil reaction $(\mathrm{pH})$ and progressive increases in soil salinity (EC), soluble ions ( $\mathrm{Ca}, \mathrm{Mg}, \mathrm{Na}, \mathrm{HCO}$, $\mathrm{Cl}$ and SO4), total soluble salts (TSS) and sodium adsorption ratio (SAR). El-Shouny (2006) reported that the addition of different rates of soil amendments, i.e., FYM and sulphur to clay soil at Kafer El-Shiekh Governorate decreased $\mathrm{pH}$ and ESP but increased the soluble cations and anions.

Abd-Allah (2014) showed that the natural soil amendments such as water hyacinth compost, rice straw compost and farmyard manure had a slightly decrease in soil $\mathrm{pH}$ and progressive increase in soil EC for the two soil depths in the two growing seasons. Also, soluble cations and anions slightly increased with all added treatments. SAR and TSS values were increased compared with the control. Exchangeable $\mathrm{Ca}, \mathrm{Mg}, \mathrm{K}$ and $\mathrm{CEC}$ were increased, while Ex. $\mathrm{Na}$ and ESP were decreased with all added amendments.

El-Maddah et al (2015) show that some natural soil amendments, i.e., farmyard manure, sheep manure, rabbit manure and pigeon manure and their combinations slightly decreased soil $\mathrm{pH}$ and progressive increased soil salinity (EC). Also, soluble cations and anions slightly increased except soluble $\mathrm{Na}$ decreased in some cases. SAR values were decreased while TSS values were increased compared with the control. Exchangeable $\mathrm{Ca}, \mathrm{Mg}$, $\mathrm{K}, \mathrm{CEC}$, organic carbon and $\mathrm{C} / \mathrm{N}$ ratio were increased with all added amendments while Ex. $\mathrm{Na}$ and ESP were decreased. Also, these amendments clearly enhanced the nutrients of the investigated soil.

Amer (2016) referred that cation exchange capacity was highly significant increased due to individual application of biochar, compost tea, or magnetic iron ore and recorded the highest values by combination of treatments after harvesting of plant. Gayathri and Srinivasamurthy (2016) indicate that higher NPK content and higher root, shoot, dry weight in soil after harvest of maize were recorded of humic acid sources extracted from different organic wastes (poultry manure, pressmud, coffee pulp and urban compost) and lower nutrient content in soil was recorded in only NPK treated soils. Guo et al (2016) demonstrated that organic matter 
and total $\mathrm{N}$ content from topsoil were significantly and positively related to cattle manure compost (CMC) input. Applying chemical fertilizers led to the lower SOM and total $\mathrm{N}$ content. Agegnehu et al (2016) found that organic amendments significantly improved soil properties through increases in soil organic carbon (SOC), cation exchange capacity (CEC). The use of biochar, compost or compost + biochar may substantially reduce the amount of mineral fertilizer required for the sustainable production of barley in the long term. Meena et al (2015) indicated the higher value of organic carbon was observed in farmyard manure applied equivalent to $120 \mathrm{~kg} \mathrm{~N} / \mathrm{ha}$ followed by vermicompost equivalent to $120 \mathrm{~kg} \mathrm{~N} / \mathrm{ha}$.

Wapa and Oyetola (2014) found that the major soil chemical properties affected by the combined application of nitrogen fertilizer and different organic manures include soil $\mathrm{pH}, \mathrm{CEC}$, soil organic carbon, total nitrogen and $\mathrm{C} / \mathrm{N}$ ratio. There was significant decrease in soil $\mathrm{pH}$, soil $\mathrm{CEC}$ and $\mathrm{C}$ : $\mathrm{N}$ ratio as nitrogen fertilizer was applied in combination with poultry droppings in 2008 and 2009 and in the combined analysis. While, there was a significant increased in soil organic carbon content, total nitrogen contents with the addition of nitrogen fertilizer application in combination with cow dung in 2008 and 2009 and in the combined analysis. Zhong et al (2014) indicated that the soil $\mathrm{pH}$ values were decreased with more $\mathrm{N}$ application at different stages. $\mathrm{N}$ application could increase the $\mathrm{N}$ contents of leaf and stem, whereas less or excess $\mathrm{N}$ application should not significant improve maize yield. Reasonable $\mathrm{N}$ fertilizer amount $(241.5 \mathrm{~kg} / \mathrm{ha})$ and application at two stages $(30 \%$ at sowing and $70 \%$ at jointing stage) could significant increase $\mathrm{N}$ utilization efficiency and improve maize yield.

The purpose of this work is to find out the direct and residual effects of compost rates at $30 \mathrm{~cm}$ mole depth, arranged in parallel orientation with respect to one another's at $3 \mathrm{~m}$ spacing or placed on the surface layer with nitrogen fertilizer rates on improving some soil chemical properties. Furthermore, the whole improvements of such soils are economically determined by calculating the net income for all treatments.

\section{MATERIALS AND METHODS}

Two field experiments were conducted at ElGemmeiza Agricultural Research Station, ElGharbia Governorate during two consecutive growing seasons (summer season 2017 and winter season 2017/2018). The experiment was initiated in summer season 2017 using maize plants (Zea mays) and lasted for winter season 2017/2018 using barley plants (Hordum vulgare) to study the effect and residual effects of nitrogen fertilizer and compost rates at $30 \mathrm{~cm}$ mole depth arranged in parallel orientation with respect to one another and spaced at $3 \mathrm{~m}$ aparts or mixed to $10 \mathrm{~cm}$ of surface soil layer on improving some soil chemical properties and some macronutrients content. Some soil properties of the experimental soil are presented in Table (1-a) and the used compost analysis are shown in Table (1-b).

The experimental design was split-split plot with three replications. The main plots were for two application depths of compost, D1 (Surface application $\approx 10 \mathrm{~cm}$ depth) and D2 (30 cm mole depth), sub plots were for nitrogen fertilizer rates $(\mathrm{N} 1=$ zero $\%, \mathrm{~N} 2=50 \%, \mathrm{~N} 3=75 \%$ and N4 $=100 \%$ of recommended dose for each crop) and sub-sub plots were for compost rates $(\mathrm{C} 1=$ zero, $\mathrm{C} 2=2.5$, C3 $=5.0$ and C4 $=7.5$ ton $\left.\mathrm{fed}^{-1}\right)$. The plot area of the experiment was $24 \mathrm{~m}^{2}(4 \mathrm{~m} \times 6 \mathrm{~m})$ where the area of the experiment was divided into 32 plots for each replicate.

The moles were constructed at $30 \mathrm{~cm}$ depth by special ditcher, then the compost was placed on the soil surface or filled moles manual. The addition of compost were done before maize sowing in the first season only and the residual effect of compost was studied on barley crop in the second one, where the same experimental plots were left without application of compost to study the residual effects in the first season.

Maize grains (Zea mays L.) single cross 10 maize hybrid were planted (Summer 2017) at the rate of $10 \mathrm{~kg} \mathrm{fed}^{-1}$ during the first week of June 2017. While, barley grains (Hordum vulgare L.) cultivar Giza 126 were planted in the second season at the rate of $50 \mathrm{~kg} \mathrm{fed}^{-1}$ during the third week of December 2017.

During the two seasons, the basal doses of $\mathrm{P}$ in the form of mono supper phosphate, $15.5 \%$ $\mathrm{P}_{2} \mathrm{O}_{5}$ and $\mathrm{K}$ in the form of potassium sulphate, 48 $\% \mathrm{~K}_{2} \mathrm{O}$ were applied according to the recommendations for each crop, $31 \mathrm{Kg} \mathrm{P}_{2} \mathrm{O}_{5}$ fed $^{-1}$ and $48 \mathrm{Kg}$ $\mathrm{K}_{2} \mathrm{O}$ fed $^{-1}$, for maize and $15.5 \mathrm{Kg} \mathrm{P}_{2} \mathrm{O}_{5}$ fed $^{-1}$ and 24 $\mathrm{Kg} \mathrm{K}_{2} \mathrm{O}$ fed $^{-1}$ for barley. While, the recommended dose of $\mathrm{N}$ fertilizer, $120 \mathrm{Kg} \mathrm{N}$ fed ${ }^{-1}$ for maize and $45 \mathrm{Kg} \mathrm{N} \mathrm{fed}^{-1}$ for barley, were applied in the form of ammonium nitrate, $33.5 \% \mathrm{~N}$. The normal agricultural practices except those under study were carried out as usual for each crop according to the recommendations of El-Gemmeiza Research Station. 
Table 1-a. Some soil properties of the experimental site

\begin{tabular}{|c|c|c|c|c|c|c|c|}
\hline \multicolumn{2}{|c|}{ Soil depth, cm } & $0-10$ & $10-30$ & \multicolumn{2}{|c|}{ Soil depth, cm } & $0-10$ & $10-30$ \\
\hline \multicolumn{8}{|c|}{ Physical properties } \\
\hline \multicolumn{4}{|c|}{ Particle size distribution } & \multicolumn{2}{|l|}{ Texture class } & $\begin{array}{l}\text { Clay } \\
\text { loam }\end{array}$ & $\begin{array}{l}\text { Clay } \\
\text { loam }\end{array}$ \\
\hline \multirow{2}{*}{\multicolumn{2}{|c|}{$\begin{array}{l}\text { Coarse sand, \% } \\
\text { Fine sand, \% }\end{array}$}} & 5.17 & 4.65 & \multirow{4}{*}{\multicolumn{2}{|c|}{$\begin{array}{c}\text { Bulk density }\left(\mathrm{Db}, \mathrm{g} \mathrm{cm}^{-3}\right) \\
\text { Total porosity }(\mathrm{E}, \%) \\
\text { Hydraulic conductivity }(\mathrm{Kh}, \mathrm{cm} \\
\left.\mathrm{hr}^{-1}\right) \\
\mathrm{CaCO}_{3}, \%\end{array}$}} & 1.38 & 1.41 \\
\hline & & 19.77 & 19.81 & & & 47.92 & 46.79 \\
\hline \multicolumn{2}{|c|}{ Silt, \% } & 36.96 & 35.93 & & & 0.47 & 0.44 \\
\hline \multicolumn{2}{|c|}{ Clay, \% } & 38.10 & 39.61 & & & 3.44 & 3.32 \\
\hline \multicolumn{8}{|c|}{ Chemical properties } \\
\hline \multirow{2}{*}{\multicolumn{2}{|c|}{$\begin{array}{c}\mathrm{pH}, 1: 2.5 \text { (susp.) } \\
\mathrm{EC}, \mathrm{dSm}^{-1}\end{array}$}} & 7.76 & 7.78 & \multirow{4}{*}{$\begin{array}{c}\text { Exchangeable } \\
\text { cations, meq/100g } \\
\text { soil }\end{array}$} & $\mathrm{Ca}$ & 21.21 & 20.28 \\
\hline & & 1.70 & 1.73 & & $\mathrm{Mg}$ & 14.83 & 14.38 \\
\hline \multirow{8}{*}{$\begin{array}{l}\text { Soluble ions, } \\
\text { meq l-1 }\end{array}$} & $\mathrm{Ca}^{2+}$ & 5.10 & 5.03 & & $\mathrm{Na}$ & 5.95 & 5.84 \\
\hline & $\mathrm{Mg}^{2+}$ & 3.77 & 3.42 & & $\mathrm{~K}$ & 0.64 & 1.04 \\
\hline & $\mathrm{Na}^{+}$ & 8.53 & 8.87 & \multirow{2}{*}{\multicolumn{2}{|c|}{$\begin{array}{c}\text { CEC, } \mathrm{meq} / 100 \mathrm{~g} \text { soil } \\
\text { ESP, } \%\end{array}$}} & 42.63 & 41.54 \\
\hline & $\mathrm{K}^{+}$ & 0.11 & 0.08 & & & 13.96 & 14.06 \\
\hline & $\mathrm{CO}_{3}^{2-}$ & 0.00 & 0.00 & \multirow{3}{*}{$\begin{array}{c}\text { Total macronutrients, } \\
\%\end{array}$} & $\mathrm{~N}$ & 0.137 & 0.127 \\
\hline & $\mathrm{HCO}^{3-}$ & 2.30 & 2.45 & & $P$ & 0.031 & 0.029 \\
\hline & $\mathrm{Cl}^{-}$ & 7.86 & 7.91 & & $\mathrm{~K}$ & 0.317 & 0.304 \\
\hline & $\mathrm{SO}_{4}^{2-}$ & 6.84 & 6.94 & \multicolumn{2}{|c|}{ Organic matter (O.M, \%) } & 2.53 & 2.25 \\
\hline \multirow{2}{*}{\multicolumn{2}{|c|}{$\begin{array}{c}\text { SAR } \\
\text { TSS, \% }\end{array}$}} & 4.17 & 4.34 & \multirow{2}{*}{\multicolumn{2}{|c|}{$\begin{array}{c}\text { Organic carbon (O.C, \%) } \\
\mathrm{C} / \mathrm{N} \text { ratio }\end{array}$}} & 1.465 & 1.304 \\
\hline & & 0.08 & 0.08 & & & 10.69 & 10.27 \\
\hline
\end{tabular}

Table 1-b. Some chemical characteristics of the investigated compost

\begin{tabular}{|l|c|l|c|}
\hline \multicolumn{1}{|c|}{ Properties } & Compost & \multicolumn{1}{|c|}{ Properties } & Compost \\
\hline $\mathrm{pH}(1: 10$ compost: water) & 7.39 & Bulk density, $\mathrm{g} / \mathrm{cm}^{3}$ & 0.57 \\
$\mathrm{EC}, \mathrm{dS} \mathrm{m} \mathrm{m}^{-1}(1: 10$ manure:water $)$ & 3.19 & Moisture content, \% & 18.00 \\
$\mathrm{Ca}, \%$ & 0.84 & Ash, \% & 66.33 \\
$\mathrm{Mg}, \%$ & 0.29 & Organic matter, \% & 33.67 \\
$\mathrm{Na}, \%$ & 0.27 & Organic carbon, \% & 19.53 \\
$\mathrm{Cl} \%$ & 0.14 & Total N, \% & 1.57 \\
$\mathrm{Fe}, \mathrm{ppm}$ & 1215.00 & C/N ratio & 12.44 \\
$\mathrm{Zn}, \mathrm{ppm}$ & 83.15 & Total P, \% & 0.95 \\
$\mathrm{Mn}, \mathrm{ppm}$ & 72.80 & Total K, \% & 1.6 \\
$\mathrm{Cu}, \mathrm{ppm}$ & 31.25 & & \\
\hline
\end{tabular}

The compost was placed and mixed with surface soil layer by chisel plow ( 9 shares) two passes at an average depth of $10 \mathrm{~cm}$ and underground moles $3 \mathrm{~m}$ spacing at $30 \mathrm{~cm}$ depth, with rate of 0.0 , 2.5, 5.0 and 7.5 ton $^{-1}$ fedore sowing. $^{-1}$ befor

At harvesting of each growing season, soil samples (10 and $30 \mathrm{~cm}$ depths) were collected after crop harvesting. The collected soil samples were air-dried, ground and passed through $2 \mathrm{~mm}$ sieve and stored for chemical analysis.

Soil $\mathrm{pH}$ in soil water suspension (1: 2.5) and soil electrical conductivity $\left(\mathrm{EC}, \mathrm{dSm}^{-1}\right)$ in soil paste extract were measured. Soluble cations and anions were determined in soil paste extract using the methods described by Page et al. (1982).

Sodium Adsorption Ratio (SAR) was calculated as:

$$
\mathrm{SAR}=\frac{\mathrm{Na} \mathrm{meq} / \mathrm{I}}{\sqrt{\frac{\mathrm{Ca}+\mathrm{Mg} \mathrm{meq} / \mathrm{I}}{2}}}
$$

Total soluble salts, \% were calculated according to the following equation: 


$$
\text { T.S.S., } \%=\frac{E C d S m^{-1} \times 0.064 \times S P}{100}
$$

Where: SP = Saturation percentage

Cation exchange capacity (CEC, meq/100g soil) was determined using sodium acetate solution 1.0 $\mathrm{N}$ with $\mathrm{pH}$ 8.2, exchangeable cations (meq/100g soil) were displaced using $1.0 \mathrm{~N}$ ammonium acetate solution. Exchangeable sodium percentage (ESP, \%) was calculated according to the following equation :

$$
E S P, \%=\frac{E X . N a \text { meq/100g.soil }}{C E C \text { meq/100g.soil }} \times 100
$$

Organic matter was determined by Walkely and Black method according to Black (1965). Total NPK of the soil were determined according to Hesse (1971). Total nitrogen by macro-Kjeldahel method, total phosphorus by ascorbic acid molybdenum blue method and total potassium by flame photometer method.

Economic evaluation was done to compare between different treatments to state which one is more reliable. The test was executed according to the price of the yield (2000 L.E. ton ${ }^{-1}$ maize in the first season and 4000 L.E. ton ${ }^{-1}$ seed of barley and 1000 L.E. ton ${ }^{-1}$ straw of barley in the second season), as well as the cost of different treatments including the price of plowing which was calculated considering conventional method of estimating both fixed and variable costs. The collected data were statistically analyzed according to procedure out lined by Sendecor and Cochran (1981).

\section{RESULTS AND DISCUSSION}

I- Effect of different treatments on some soil chemical properties

\section{1- Soil reaction $(\mathrm{pH})$}

The effect of compost rates filled $30 \mathrm{~cm}$ mole depth or placed on the surface soil layer with nitrogen fertilizer rates on soil reaction $(\mathrm{pH})$ are shown in Tables ( 2 and 3 ). The results indicate that, all different treatments led to slightly decreases in soil $\mathrm{pH}$ for the two growing seasons. The lowest $\mathrm{pH}$ value was obtained by the addition of 7.5 ton compost fed ${ }^{-1}$ in $30 \mathrm{~cm}$ mole depth with $100 \%$ recommended dose of nitrogen fertilizer for each crop, which decreased to 7.12 and 7.08 in the first and second seasons, respectively. These results reveal that the decrease in soil $\mathrm{pH}$ values may have been caused by soil microbial activity that produced $\mathrm{CO} 2$ and organic acids. Modification of soil $\mathrm{pH}$ is more important because microbial activity decreases blow 6 or increases above 7 (Mohammad and Battikhi, 1997). Similar conclusion was obtained by ElSodany et al (2007), they showed that the organic residues filled moles at different depths slightly decrease the soil reaction $(\mathrm{pH})$.

The results also reveal that the application depth was significantly decrease soil $\mathrm{pH}$, where the use of $30 \mathrm{~cm}$ mole depth (D2) decreased it more than surface depth (D1). The decreases of soil $\mathrm{pH}$ mean values reached to 7.39 and 7.34 at $30 \mathrm{~cm}$ mole depth, while the surface depth reached to 7.43 and 7.38 in the first and second seasons, respectively. This reduction may be due to the fact that the mole drains allow water and organic acids resulted from organic matter decomposition to percolate and downward taking them to deeper layer of soil. Similar results was obtained by El-Maddah et al (2007).

The results from these tables show that increasing nitrogen fertilizer rates gave significant decreases in soil $\mathrm{pH}$, where the lowest $\mathrm{pH}$ mean value was recorded by the addition of $100 \%$ of recommended dose nitrogen fertilizer for each crop under the experimental treatments, which decreased to 7.21 and 7.16 of the first and second seasons, respectively. These results may be due to by increasing $\mathrm{N}$ fertilizer rates the $\mathrm{C} / \mathrm{N}$ ratio in soil became narrow which led to accelerate the decomposition of organic substances causing decreases in soil $\mathrm{pH}$. These results are in line with Wapa and Oyetola (2014) and Zhong et al (2014).

Also, the results show that the addition of compost rates obtained significant decreases in soil $\mathrm{pH}$. The lowest $\mathrm{pH}$ mean value was recorded by the addition of 7.5 ton compost fed ${ }^{-1}$, which decreased to 7.35 and 7.30 of the first and second seasons, respectively. These results reveal that there is no wide variation between these added treatments on soil $\mathrm{pH}$ values. This may be due to the magnitude of $\mathrm{pH}$ change depends on many soil properties, including buffering capacity and length of time after the application organic material. Modification of soil $\mathrm{pH}$ is also important because trace metals became more plant available as the $\mathrm{pH}$ decreases. In addition, microbial activity decreases as the $\mathrm{pH}$ decreases below 6 or increases above 7. Similar conclusion was obtained by El-Shouny (2006), who reported that application of different rates of soil amendments, i.e., FYM and sulphur to clay soil at kafer El-Shiekh Governorate decreased $\mathrm{pH}$. These results are also in line with El-Maddah et al (2012) and El-Sodany et al (2016). 
Table 2. Effect of different treatments on some soil chemical properties after maize in the first season (summer 2017)

\begin{tabular}{|c|c|c|c|c|c|c|c|c|c|c|c|c|c|}
\hline \multirow{2}{*}{$\begin{array}{l}\text { Application } \\
\text { depth cm }\end{array}$} & \multirow{2}{*}{$\begin{array}{l}\text { Nitrogen } \\
\text { fertilizer }\end{array}$} & \multirow{2}{*}{$\begin{array}{c}\text { Compost } \\
\text { rates } \\
\text { (ton fed }^{-1} \text { ) }\end{array}$} & \multirow{2}{*}{$\begin{array}{l}\text { H, 1:2. } \\
\text { (susp.) }\end{array}$} & \multirow{2}{*}{$\begin{array}{l}E C \\
d^{-1} m^{-1}\end{array}$} & \multicolumn{4}{|c|}{ Cations, meq I ${ }^{-1}$} & \multicolumn{3}{|c|}{ Anions, meq l$^{-1}$} & \multirow[b]{2}{*}{ SAR } & \multirow[b]{2}{*}{ TSS, \% } \\
\hline & & & & & $\mathrm{Ca}^{++}$ & $\mathbf{M g}^{++}$ & $\mathrm{Na}^{+}$ & $\mathbf{K}^{+}$ & $\mathrm{HCO}_{3}{ }^{-}$ & $\mathrm{Cl}^{-}$ & $\mathrm{SO}_{4}^{--}$ & & \\
\hline \multirow{16}{*}{ D1 } & \multirow{4}{*}{ N1 } & C1 & 7.75 & 1.68 & 5.06 & 3.18 & 8.45 & 0.11 & 2.25 & 7.81 & 6.74 & 4.16 & 0.08 \\
\hline & & C2 & 7.63 & 1.92 & 5.64 & 4.30 & 9.04 & 0.22 & 2.95 & 9.03 & 7.22 & 4.05 & 0.10 \\
\hline & & C3 & 7.61 & 1.94 & 5.78 & 4.33 & 9.06 & 0.23 & 2.99 & 9.12 & 7.29 & 4.03 & 0.10 \\
\hline & & C4 & 7.59 & 1.97 & 5.84 & 4.53 & 9.10 & 0.23 & 3.04 & 9.33 & 7.33 & 4.00 & 0.10 \\
\hline & \multirow{4}{*}{ N2 } & C1 & 7.65 & 2.03 & 5.93 & 4.92 & 9.31 & 0.14 & 3.01 & 9.43 & 7.86 & 4.00 & 0.10 \\
\hline & & C2 & 7.44 & 2.12 & 6.33 & 5.23 & 9.41 & 0.23 & 3.25 & 9.97 & 7.98 & 3.91 & 0.11 \\
\hline & & $\mathrm{C} 3$ & 7.43 & 2.17 & 6.53 & 5.47 & 9.46 & 0.24 & 3.28 & 10.37 & 8.05 & 3.86 & 0.11 \\
\hline & & C4 & 7.42 & 2.19 & 6.55 & 5.61 & 9.49 & 0.25 & 3.30 & 10.44 & 8.16 & 3.85 & 0.12 \\
\hline & \multirow{4}{*}{ N3 } & $\mathrm{C} 1$ & 7.47 & 2.09 & 6.23 & 5.12 & 9.33 & 0.22 & 3.11 & 9.80 & 7.99 & 3.92 & 0.10 \\
\hline & & C2 & 7.32 & 2.25 & 6.97 & 5.72 & 9.56 & 0.25 & 3.32 & 10.52 & 8.66 & 3.80 & 0.11 \\
\hline & & C3 & 7.31 & 2.28 & 7.09 & 5.84 & 9.61 & 0.26 & 3.38 & 10.65 & 8.77 & 3.78 & 0.12 \\
\hline & & C4 & 7.30 & 2.29 & 7.12 & 5.89 & 9.62 & 0.27 & 3.41 & 10.70 & 8.79 & 3.77 & 0.12 \\
\hline & \multirow{4}{*}{ N4 } & C1 & 7.35 & 2.37 & 7.39 & 6.30 & 9.71 & 0.30 & 3.20 & 11.46 & 9.04 & 3.71 & 0.11 \\
\hline & & C2 & 7.19 & 2.51 & 8.23 & 6.55 & 9.95 & 0.37 & 4.61 & 11.72 & 8.77 & 3.66 & 0.12 \\
\hline & & C3 & 7.18 & 2.66 & 8.89 & 7.16 & 10.17 & 0.38 & 4.78 & 12.14 & 9.68 & 3.59 & 0.14 \\
\hline & & C4 & 7.17 & 2.89 & 10.00 & 8.20 & 10.31 & 0.39 & 4.86 & 12.40 & 11.64 & 3.42 & 0.15 \\
\hline & \multirow{4}{*}{ N1 } & C1 & 7.73 & 1.64 & 4.69 & 3.27 & 8.37 & 0.07 & 2.23 & 7.61 & 6.56 & 4.20 & 0.08 \\
\hline & & C2 & 7.57 & 1.69 & 4.89 & 3.40 & 8.45 & 0.16 & 2.31 & 7.72 & 6.87 & 4.15 & 0.09 \\
\hline & & C3 & 7.55 & 1.72 & 5.04 & 3.51 & 8.48 & 0.17 & 2.42 & 7.86 & 6.92 & 4.10 & 0.09 \\
\hline & & $\mathrm{C} 4$ & 7.54 & 1.75 & 5.13 & 3.71 & 8.49 & 0.17 & 2.55 & 7.91 & 7.04 & 4.04 & 0.10 \\
\hline & \multirow{4}{*}{ N2 } & $\mathrm{C}$ & $\begin{array}{ll}7.58 \\
\end{array}$ & 1.86 & 5.60 & 4.27 & 8.57 & 0.16 & 2.57 & 8.86 & 7.17 & 3.86 & 0.09 \\
\hline & & C2 & 7.41 & 2.11 & 6.57 & 5.27 & 9.05 & 0.21 & 2.96 & 10.35 & 7.79 & 3.72 & 0.11 \\
\hline & & C3 & 7.40 & 2.12 & 6.59 & 5.34 & 9.06 & 0.21 & 2.98 & 10.40 & 7.82 & 3.71 & 0.11 \\
\hline & & $\mathrm{C} 4$ & 7.39 & 2.14 & 6.66 & 5.45 & 9.08 & 0.21 & 3.02 & 10.52 & 7.86 & 3.69 & 0.12 \\
\hline & \multirow{4}{*}{ N3 } & $\mathrm{C} 1$ & 7.46 & 1.91 & 5.79 & 4.45 & 8.67 & 0.19 & 2.80 & 9.11 & 7.19 & 3.83 & 0.09 \\
\hline & & C2 & 7.28 & 1.97 & 6.15 & 4.51 & 8.78 & 0.26 & 2.85 & 9.55 & 7.30 & 3.80 & 0.10 \\
\hline & & C3 & 7.27 & 1.98 & 6.18 & 4.55 & 8.79 & 0.28 & 2.87 & 9.61 & 7.32 & 3.79 & 0.11 \\
\hline & & C & 7.26 & 2.00 & 6.26 & 4.64 & 8.81 & 0.29 & 2.90 & 9.68 & 7.42 & 3.77 & 0.11 \\
\hline & \multirow{4}{*}{ N4 } & $\mathrm{C} 1$ & 7.34 & 2.25 & 7.20 & 5.80 & 9.25 & 0.25 & 3.30 & 11.00 & 8.20 & 3.63 & 0.11 \\
\hline & & C2 & 7.15 & 2.26 & 7.24 & 5.84 & 9.26 & 0.26 & 3.34 & 11.04 & 8.22 & 3.62 & 0.12 \\
\hline & & C3 & 7.14 & 2.32 & 7.43 & 6.11 & 9.34 & 0.32 & 3.63 & 11.24 & 8.33 & 3.59 & 0.13 \\
\hline & & C4 & & 2.3 & & 6.34 & 9.39 & 0.32 & 3.86 & & 8.50 & 3.55 & 0.13 \\
\hline & D1 & urface) & 7.43 & 2.21 & 6.8 & 5.52 & 9.47 & 0.26 & 3.42 & 10.31 & 8.37 & 3.84 & 0.11 \\
\hline $\begin{array}{l}\text { A Application } \\
\text { depth cm }\end{array}$ & D? & $30 \mathrm{~cm})$ & 7.39 & 2.01 & 6.19 & 4.78 & 8.87 & 0.22 & 2.91 & 9.61 & 7.53 & 3.82 & 0.11 \\
\hline & & & & & & & & & & & & $\star *$ & \\
\hline & & $(0 \%)$ & 7.62 & 1.79 & 5.26 & 3.78 & 8.68 & 0.17 & 2.59 & 8.30 & 7.00 & 4.09 & 0.09 \\
\hline & N2 & (50\%) & 7.47 & 2.09 & 6.35 & 5.20 & 9.18 & 0.21 & 3.05 & 10.04 & 7.84 & 3.83 & 0.11 \\
\hline $\begin{array}{l}\text { Nitrogen } \\
\text { fortilizer }\end{array}$ & & $(75 \%)$ & 7.33 & 2.10 & 6.47 & 5.09 & 9.15 & 0.25 & 3.08 & 9.95 & 7.93 & 3.81 & 0.11 \\
\hline & & $100 \%)$ & $\underset{* *}{7.21}$ & $\underset{* *}{2.45}$ & 8.00 & 6.54 & 9.67 & 0.32 & 3.95 & 11.54 & 9.05 & $\underset{\star *}{3.60}$ & 0.13 \\
\hline & & $1(0)$ & 7.54 & 1.98 & & 4.66 & 8.96 & 0.18 & 2.81 & 9.39 & 7.59 & 3.91 & 0.10 \\
\hline & & (2.5) & 7.37 & 2.10 & 6.50 & 5.10 & 9.19 & 0.25 & 3.20 & 9.99 & 7.85 & 3.84 & 0.11 \\
\hline C Compos & & $3(5)$ & 7.36 & 2.15 & 6.69 & 5.29 & 9.25 & 0.26 & 3.29 & 10.17 & 8.02 & 3.81 & 0.11 \\
\hline & & (7.5) & 7.35 & 2.20 & 6.90 & 5.55 & 9.29 & 0.27 & 3.37 & 10.29 & 8.34 & 3.76 & 0.12 \\
\hline & & & & & & & & & & & & & \\
\hline
\end{tabular}

\section{2- Soil salinity (EC) and soluble ions}

Data in Tables (2 and 3) show that all different treatments caused a significant affects on soil EC values. The highest values were obtained by the addition of 7.5 ton compost fed ${ }^{-1}$ in $10 \mathrm{~cm}^{\text {depth with }}$ $100 \%$ recommended dose of nitrogen fertilizer for each crop, where it increased to 2.89 and 2.95
$\mathrm{dSm}^{-1}$ in the first and second seasons, respectively as compared with other treatments. Similar results were obtained by Eghball et al (2004). These results reveal that the highest values of soil EC may be due to the addition of nitrogen fertilizer or compost, where the EC values were decreased with increasing depth to $30 \mathrm{~cm}$. Similar conclusion was obtained by El-Maddah and El-Sodany (2003). 

on some soil chemical properties

Table 3. Effect of different treatments on some soil chemical properties after barley in the second season (winter 2017/2018)

\begin{tabular}{|c|c|c|c|c|c|c|c|c|c|c|c|c|c|}
\hline \multirow{2}{*}{$\begin{array}{l}\text { Application } \\
\text { depth } \mathrm{cm}\end{array}$} & \multirow{2}{*}{$\begin{array}{l}\text { Nitrogen } \\
\text { fertilizer }\end{array}$} & \multirow{2}{*}{$\begin{array}{c}\text { Compost } \\
\text { rates } \\
\text { (ton fed }^{-1} \text { ) }\end{array}$} & \multirow{2}{*}{$\begin{array}{c}\text { pH, } \\
1: 2.5 \\
\text { (susp.) }\end{array}$} & \multirow{2}{*}{$\begin{array}{c}E C, \\
d^{-1} m^{-1}\end{array}$} & \multicolumn{4}{|c|}{ Cations, meq l-1 } & \multicolumn{3}{|c|}{ Anions, meq $\mathrm{l}^{-1}$} & \multirow[b]{2}{*}{ SAR } & \multirow{2}{*}{$\begin{array}{c}\text { TSS } \\
\%\end{array}$} \\
\hline & & & & & $\mathrm{Ca}^{++}$ & $\mathrm{Mg}^{++}$ & $\mathrm{Na}^{+}$ & $\mathrm{K}^{+}$ & $\mathrm{HCO}_{3}^{-}$ & $\mathrm{Cl}^{-}$ & $\mathrm{SO}_{4}^{--}$ & & \\
\hline \multirow{16}{*}{ D1 } & \multirow{4}{*}{ N1 } & $\mathrm{C} 1$ & 7.74 & 1.73 & 4.44 & 3.29 & 9.48 & 0.09 & 2.54 & 8.01 & 6.75 & 4.82 & 0.08 \\
\hline & & $\mathrm{C} 2$ & 7.58 & 2.10 & 5.76 & 4.66 & 10.43 & 0.15 & 3.93 & 9.49 & 7.58 & 4.57 & 0.11 \\
\hline & & C3 & 7.56 & 2.14 & 5.91 & 4.88 & 10.45 & 0.16 & 3.96 & 9.80 & 7.64 & 4.50 & 0.11 \\
\hline & & $\mathrm{C} 4$ & 7.54 & 2.16 & 5.97 & 4.97 & 10.49 & 0.17 & 3.99 & 9.91 & 7.70 & 4.49 & 0.12 \\
\hline & \multirow{4}{*}{ N2 } & $\mathrm{C} 1$ & 7.59 & 2.24 & 6.02 & 4.99 & 11.19 & 0.20 & 3.71 & 10.37 & 8.32 & 4.77 & 0.11 \\
\hline & & $\mathrm{C} 2$ & 7.39 & 2.37 & 6.50 & 5.65 & 11.25 & 0.30 & 4.20 & 11.05 & 8.45 & 4.56 & 0.12 \\
\hline & & C3 & 7.38 & 2.39 & 6.64 & 5.67 & 11.27 & 0.32 & 4.23 & 11.18 & 8.49 & 4.54 & 0.13 \\
\hline & & $\mathrm{C} 4$ & 7.37 & 2.43 & 6.84 & 5.77 & 11.36 & 0.33 & 4.26 & 11.33 & 8.71 & 4.52 & 0.13 \\
\hline & \multirow{4}{*}{ N3 } & $\mathrm{C} 1$ & 7.42 & 2.26 & 6.13 & 5.09 & 11.24 & 0.14 & 4.08 & 10.46 & 8.06 & 4.75 & 0.11 \\
\hline & & $\mathrm{C} 2$ & 7.27 & 2.46 & 7.30 & 5.69 & 11.35 & 0.26 & 4.73 & 11.46 & 8.41 & 4.45 & 0.12 \\
\hline & & $\mathrm{C} 3$ & 7.26 & 2.47 & 7.34 & 5.73 & 11.36 & 0.27 & 4.78 & 11.48 & 8.44 & 4.44 & 0.13 \\
\hline & & $\mathrm{C} 4$ & 7.25 & 2.50 & 7.49 & 5.84 & 11.39 & 0.28 & 4.89 & 11.58 & 8.53 & 4.41 & 0.14 \\
\hline & \multirow{4}{*}{ N4 } & $\mathrm{C} 1$ & 7.30 & 2.57 & 7.71 & 6.41 & 11.29 & 0.29 & 4.39 & 12.02 & 9.29 & 4.25 & 0.13 \\
\hline & & $\mathrm{C} 2$ & 7.15 & 2.78 & 8.44 & 7.58 & 11.41 & 0.37 & 5.12 & 12.99 & 9.69 & 4.03 & 0.14 \\
\hline & & C3 & 7.14 & 2.87 & 8.86 & 7.94 & 11.52 & 0.38 & 5.14 & 13.31 & 10.25 & 3.97 & 0.15 \\
\hline & & $\mathrm{C} 4$ & 7.13 & 2.95 & 9.13 & 8.38 & 11.60 & 0.39 & 5.18 & 13.39 & 10.93 & 3.92 & 0.16 \\
\hline \multirow{16}{*}{ D2 } & \multirow{4}{*}{ N1 } & C1 & 7.68 & 1.63 & 4.17 & 2.94 & 9.14 & 0.05 & 2.17 & 7.74 & 6.39 & 4.85 & 0.08 \\
\hline & & $\mathrm{C} 2$ & 7.51 & 1.81 & 4.97 & 3.50 & 9.56 & 0.07 & 2.74 & 8.49 & 6.87 & 4.65 & 0.09 \\
\hline & & C3 & 7.50 & 1.83 & 4.98 & 3.62 & 9.63 & 0.07 & 2.80 & 8.55 & 6.95 & 4.64 & 0.10 \\
\hline & & $\mathrm{C} 4$ & 7.48 & 1.88 & 5.14 & 3.91 & 9.67 & 0.08 & 2.92 & 8.87 & 7.01 & 4.55 & 0.10 \\
\hline & \multirow{4}{*}{ N2 } & $\mathrm{C} 1$ & 7.52 & 2.07 & 5.95 & 4.28 & 10.33 & 0.14 & 2.76 & 10.02 & 7.92 & 4.57 & 0.10 \\
\hline & & $\mathrm{C} 2$ & 7.36 & 2.12 & 6.07 & 4.48 & 10.43 & 0.22 & 3.07 & 10.14 & 7.99 & 4.54 & 0.11 \\
\hline & & C3 & 7.35 & 2.15 & 6.15 & 4.62 & 10.48 & 0.25 & 3.09 & 10.32 & 8.09 & 4.52 & 0.12 \\
\hline & & $\mathrm{C} 4$ & 7.34 & 2.17 & 6.15 & 4.75 & 10.54 & 0.26 & 3.15 & 10.40 & 8.15 & 4.51 & 0.12 \\
\hline & \multirow{4}{*}{ N3 } & $\mathrm{C} 1$ & 7.41 & 2.08 & 6.05 & 4.32 & 10.37 & 0.06 & 2.78 & 10.06 & 7.96 & 4.55 & 0.10 \\
\hline & & $\mathrm{C} 2$ & 7.24 & 2.24 & 6.47 & 4.96 & 10.79 & 0.18 & 3.40 & 10.80 & 8.20 & 4.51 & 0.12 \\
\hline & & $\mathrm{C} 3$ & 7.23 & 2.27 & 6.63 & 5.03 & 10.85 & 0.19 & 3.44 & 10.95 & 8.31 & 4.49 & 0.12 \\
\hline & & $\mathrm{C} 4$ & 7.22 & 2.29 & 6.71 & 5.11 & 10.88 & 0.20 & 3.46 & 11.11 & 8.33 & 4.48 & 0.13 \\
\hline & \multirow{4}{*}{ N4 } & $\mathrm{C} 1$ & 7.29 & 2.40 & 7.37 & 5.93 & 10.48 & 0.22 & 3.45 & 11.64 & 8.91 & 4.06 & 0.12 \\
\hline & & $\mathrm{C} 2$ & 7.11 & 2.48 & 7.47 & 6.54 & 10.50 & 0.29 & 3.71 & 12.14 & 8.95 & 3.97 & 0.13 \\
\hline & & $\mathrm{C} 3$ & 7.10 & 2.53 & 7.70 & 6.77 & 10.53 & 0.30 & 3.88 & 12.39 & 9.03 & 3.91 & 0.14 \\
\hline & & $\mathrm{C} 4$ & 7.08 & 2.56 & 7.87 & 6.86 & 10.56 & 0.31 & 4.03 & 12.43 & 9.14 & 3.89 & 0.14 \\
\hline & D1 (s) & urface) & 7.38 & 2.40 & 6.91 & 5.78 & 11.07 & 0.26 & 4.32 & 11.11 & 8.58 & 4.44 & 0.12 \\
\hline Application & D2 (3 & $30 \mathrm{~cm})$ & 7.34 & 2.16 & 6.24 & 4.85 & 10.30 & 0.18 & 3.18 & 10.38 & 8.01 & 4.42 & 0.11 \\
\hline & & test & ** & ${ }^{* *}$ & & & & & & & & ${ }^{* *}$ & * \\
\hline & $\mathrm{N} 1$ & $(0 \%)$ & 7.57 & 1.91 & 5.17 & 3.97 & 9.86 & 0.11 & 3.13 & 8.86 & 7.11 & 4.63 & 0.10 \\
\hline & N2 ( & $50 \%)$ & 7.41 & 2.24 & 6.29 & 5.03 & 10.86 & 0.25 & 3.56 & 10.60 & 8.27 & 4.57 & 0.12 \\
\hline B Nitrogen & N3 ( & 75\%) & 7.29 & 2.32 & 6.77 & 5.22 & 11.03 & 0.20 & 3.95 & 10.99 & 8.28 & 4.51 & 0.12 \\
\hline & N4 (1 & $100 \%)$ & 7.16 & 2.64 & 8.07 & 7.05 & 10.99 & 0.32 & 4.36 & 12.54 & 9.52 & 4.00 & 0.14 \\
\hline & & test & ${ }^{* *}$ & $* *$ & & & & & & & & ${ }^{* *}$ & ${ }^{* *}$ \\
\hline & & (0) & 7.49 & 2.12 & 5.98 & 4.66 & 10.44 & 0.15 & 3.24 & 10.04 & 7.95 & 4.58 & 0.10 \\
\hline & $\mathrm{C} 2$ & (2.5) & 7.33 & 2.30 & 6.62 & 5.38 & 10.72 & 0.23 & 3.86 & 10.82 & 8.27 & 4.41 & 0.12 \\
\hline C Compost & & $(5)$ & 7.32 & 2.33 & 6.78 & 5.53 & 10.76 & 0.24 & 3.92 & 11.00 & 8.40 & 4.38 & 0.13 \\
\hline & C4 & (7.5) & 7.30 & 2.37 & 6.91 & 5.70 & 10.81 & 0.25 & 3.99 & 11.13 & 8.56 & 4.35 & 0.13 \\
\hline & & test & $\star *$ & $\star * *$ & & & & & & & & $\star *$ & $\star *$ \\
\hline
\end{tabular}


The results indicate that the increasing of application depth led to significantly decreases on EC values as compared with the surface depth, where the use of $30 \mathrm{~cm}$ mole depth was more effective on decreasing EC values than $10 \mathrm{~cm}$ surface depth. The lowest EC values were obtained by the use of $30 \mathrm{~cm}$ mole depth (D2) compared with surface depth (D1), where the EC mean values were decreased from 2.21 to $2.01 \mathrm{dSm}^{-1}$ in the first season and from 2.40 to $2.16 \mathrm{dSm}^{-1}$ in the second one, respectively. Similar conclusion was obtained by ElSodany et al (2016).

Regarding the effect of nitrogen fertilizer rates, data indicate that soil EC values were significantly increased by increasing the addition of nitrogen fertilizer, where the highest EC values were obtained by the addition of $100 \%$ recommended dose of nitrogen fertilizer for each crop. The highest EC mean values were reached to 2.45 and $2.64 \mathrm{dSm}^{-1}$ in the first and second seasons, respectively.

Also, the effect of compost rates were presented in Tables (2 and 3), the results reveal that soil EC values were significantly increased by increasing the compost rates addition. The highest $\mathrm{EC}$ mean values were recorded by the addition of 7.5 ton compost fed $^{-}$ ${ }^{1}$, which it increased to 2.20 and $2.37 \mathrm{dSm}^{-1}$ in the first and second seasons, respectively. These results are in agreement with that obtained by El-Sodany and El-Maddah (2009) and El-Sodany et al (2016)

Concerning the soluble ions, the results in Tables (2 and 3) show that the soluble ions, i.e., calcium, magnesium, sodium, potassium, bicarbonate, chloride and sulphate increased with all different treatments, which take the same trend as soil EC values. After harvesting of the first growing season, the increases of soluble $\mathrm{Ca}, \mathrm{Mg}, \mathrm{Na}, \mathrm{K}, \mathrm{HCO}_{3}, \mathrm{Cl}$ and $\mathrm{SO}_{4}$ were reached to $10.00,8.20,10.31,0.39,4.86,12.40$ and $11.64 \mathrm{meq}^{-1}$, and reached to $9.13,8.38,11.60,0.39$, $5.18,13.39$ and 10.93 meq $^{-1}$ after harvesting of the second growing season, under D1 and application of $\mathrm{N} 4$ and $\mathrm{C} 4$ treatments.

The results revealed that the application depth led to decreases in soluble ions. The lowest mean values of soluble $\mathrm{Ca}, \mathrm{Mg}, \mathrm{Na}, \mathrm{K}, \mathrm{HCO}_{3}, \mathrm{Cl}$ and $\mathrm{SO}_{4}$ were recorded at $30 \mathrm{~cm}$ mole depth, where decreased to 6.19 , $4.78,8.87,0.22,2.91,9.61$ and 7.53 meq $^{-1}$ in the first season and decreased to $6.24,4.85,10.30,0.18,3.18$, 10.38 and $8.01 \mathrm{meq}^{\mathrm{l}^{-1}}$ in the second one, respectively. On the other hand, the results show that the increases of nitrogen fertilizer rates were increased soluble ions, where the highest values were recorded by the addition of $100 \%$ recommended dose of nitro- gen fertilizer for each crop. The highest mean values of soluble $\mathrm{Ca}, \mathrm{Mg}, \mathrm{Na}, \mathrm{K}, \mathrm{HCO}_{3}, \mathrm{Cl}$ and $\mathrm{SO}_{4}$ were increased to $8.00,6.54,9.67,0.32,3.95,11.54$ and 9.05 meq $\mathrm{I}^{-1}$ in the first season and increased to $8.07,7.05$, $10.99,0.32,4.36,12.54$ and 9.52 meq $^{-1}$ in the second one, respectively.

Likewise, the results clear that the increases of compost rates addition were increased soluble ions, where the highest mean values of soluble $\mathrm{Ca}, \mathrm{Mg}, \mathrm{Na}$, $\mathrm{K}, \mathrm{HCO}_{3}, \mathrm{Cl}$ and $\mathrm{SO}_{4}$ were recorded by the addition of 7.5 ton compost fed ${ }^{-1}$, where they increased to $6.90,5.55,9.29,0.27,3.37,10.29$ and 8.34 meq $^{-1}$ in the first season, and $6.91,5.70,10.81,0.25,3.99$, 11.13 and 8.56 meq l$^{-1}$ in the second one, respectively. It can be noticed that the higher mean values of the treated soil with compost at the end of the second season compared with the first one may be due to high residual effect of this compost in the second season. These results are in agreement with that obtained by El-Shouny (2006), El-Maddah et al (2012) and El-Sodany et al (2016)

\section{3- Sodium adsorption ratio (SAR) and total soluble salts (TSS)}

Data in Tables (2 and 3) show that sodium adsorption ratio (SAR) and total soluble salts (TSS) markedly affected by the addition of compost rates filled $30 \mathrm{~cm}$ mole depth with nitrogen fertilizer rates. The lowest values of SAR and the highest values of TSS were recorded by the addition of 7.5 ton compost fed ${ }^{-1}$ in surface layer (10 cm depth) with 100 $\%$ recommended dose of nitrogen fertilizer for each crop, where the SAR value decreased to 3.42 and 3.92 , while, the TSS value increased to 0.15 and 0.16 $\%$, in the first and second seasons, respectively.

Concerning the application depth, the results indicate that the increases of application depth led to significantly decreases of SAR and TSS values. The lowest values of SAR and TSS were recorded by using 30 $\mathrm{cm}$ mole depth, where the mean values of SAR were decreased to 3.82 and 4.42 , also the mean values of TSS decreased to $0.11 \%$ in the first and second seasons, respectively. Similar results were obtained by El-Maddah and El-Sodany (2003)

Concerning the effect of nitrogen fertilizer rates, data indicate that the SAR values were significantly decreased, while, the TSS values were significantly increased by increasing nitrogen fertilizer rates addition. The lowest values of SAR and the highest values of TSS were recorded by the addition of $100 \%$ recommended dose of nitrogen fertilizer for each crop, where the mean values of SAR were decreased to 
3.60 and 4.00 , while the mean values of TSS were increased to 0.13 and $0.14 \%$ in the first and second seasons, respectively.

Data presented in Tables (2 and 3) also indicated that the addition of compost rates caused significant decreases in SAR values and significant increases in TSS. The lowest values of SAR and the highest values of TSS were recorded by the addition of 7.5 ton compost fed ${ }^{-1}$. The lowest mean values of SAR were decreased to 3.76 and 4.35 , while the highest mean values of TSS was increased to 0.12 and $0.13 \%$ in the first and second seasons, respectively. Similar results were obtained by El-Maddah and El-Sodany (2003).

II- Effect of different treatments on exchangeable cations, cation exchange capacity and exchangeable sodium percentage

\section{1- Exchangeable cations ( $\mathrm{Ca}, \mathrm{Mg}$ and $\mathrm{K}$ ) and cation exchange capacity}

The results in Table (4) show that the exchangeable cations ( $\mathrm{Ca}, \mathrm{Mg}$ and $\mathrm{K}$, meq $/ 100 \mathrm{~g}$ soil) and cation exchange capacity (CEC, meq/100g soil) were significantly affected by the addition of compost rates filled $30 \mathrm{~cm}$ mole depth with nitrogen fertilizer rates. The results indicate that the Ex. $\mathrm{Ca}, \mathrm{Mg}, \mathrm{K}$ and $\mathrm{CEC}$ were significantly increased with all different treatments, where the highest values were obtained by the addition of 7.5 ton compost $\mathrm{fed}^{-1}$ in $30 \mathrm{~cm}$ mole depth with $100 \%$ recommended dose of nitrogen fertilizer for each crop. The increases of the Ex. Ca, Mg, K and CEC were reached to $21.66,15.21,0.89$ and $43.38 \mathrm{meq} / 100 \mathrm{~g}$ soil in the first season, and reached to 21.68 , $15.24,0.90$ and $43.42 \mathrm{meq} / 100 \mathrm{~g}$ soil in the second one, respectively. Similar conclusion was obtained by El-Maddah et al. (2015) and Amer (2016).

Concerning the application depth, the results indicate that the Ex. $\mathrm{Ca}, \mathrm{Mg}, \mathrm{K}$ and $\mathrm{CEC}$ values were significantly increased by increasing the application depth as compared with the surface depth. The highest mean values of them were recorded by using $30 \mathrm{~cm}$ mole depth, where the values were reached to $21.49,15.03,0.81$ and $43.07 \mathrm{meq} / 100 \mathrm{~g}$ soil in the first season, while in the second one, they were reached to $21.51,15.06,0.83$ and 43.11 meq $/ 100 \mathrm{~g}$ soil, respectively.

Data in Table (4) indicate that increasing nitrogen fertilizer rates led to significantly increases of the Ex. $\mathrm{Ca}, \mathrm{Mg}, \mathrm{K}$ and $\mathrm{CEC}$ values, where the highest values were obtained by the addition of $100 \%$ recommended dose of nitrogen fertilizer for each crop. The highest mean values of Ex. $\mathrm{Ca}, \mathrm{Mg}, \mathrm{K}$ and CEC were 21.54, 15.09, 0.84 and $43.16 \mathrm{meq} / 100 \mathrm{~g}$ in the first season, and were 21.57, 15.13, 0.85 and $43.22 \mathrm{meq} / 100 \mathrm{~g}$ soil in the second one, respectively. These results may be due to accelerating of organic materials decomposition resulting increases in CEC and ex. cations in soil. Similar results were obtained by Abd-Allah (2014) and Wapa and Oyetola (2014)

Regarding the addition of compost rates, the results reveal that the $\mathrm{Ex}$. $\mathrm{Ca}, \mathrm{Mg}, \mathrm{K}$ and $\mathrm{CEC}$ values were significantly increased with increasing compost rates. The highest mean values were recorded by the addition of 7.5 ton compost fed ${ }^{-1}$, where they reached to $21.54,15.12,0.91$ and $43.26 \mathrm{meq} / 100 \mathrm{~g}$ soil in the first season, and reached to 21.57 , $15.15,0.92$ and $43.30 \mathrm{meq} / 100 \mathrm{~g}$ in the second one. Similar results were obtained by El-hady \& Abo-Sedera (2006), El-Maddah et al (2012) and Agegnehu et al (2016).

\section{2- Exchangeable sodium and exchangeable so- dium percentage}

The results in Table (4) indicate that the Ex. Na (meq/100 $\mathrm{g}$ soil) and the exchangeable sodium percentage (ESP, \%) were significantly decreased with all treatments at the two soil depths (10 and $30 \mathrm{~cm}$ ) in the two seasons. The lowest values of Ex. Na and ESP were caused by the addition of 7.5 ton compost fed ${ }^{-1}$ filled $30 \mathrm{~cm}$ mole depth with $100 \%$ recommended dose of nitrogen fertilizer for each crop, where they decreased to 5.62 and 5.60 $\mathrm{meq} / 100 \mathrm{~g}$ soil for Ex. $\mathrm{Na}$ and 12.96 and $12.90 \%$ for ESP, in the first and second seasons, respectively. Similar results were obtained by El-Shouny (2006).

The results in the same table reveal that the Ex. $\mathrm{Na}$ and ESP values were significantly decreased by increasing the application depth, where the use of $30 \mathrm{~cm}$ mole depth was more effective than surface application on decreasing Ex. $\mathrm{Na}$ and ESP values. The decreases mean values of Ex. $\mathrm{Na}$ were reached to 5.74 and $5.72 \mathrm{meq} / 100 \mathrm{~g}$ soil, also the decreases of ESP were reach to 13.33 and $13.27 \%$ in the first and second seasons, respectively.

Regarding the application of nitrogen fertilizer rates, it can be noticed that the Ex. Na and ESP values were significantly decreased with increasing nitrogen fertilizer rates, where the lowest values were recorded by using $100 \%$ recommended dose of nitrogen fertilizer for each crop. The lowest mean values of Ex. Na and ESP were decreased to 5.69 meq $/ 100 \mathrm{~g}$ soil, $13.18 \%$ in the first season, and to be $5.68 \mathrm{meq} / 100 \mathrm{~g}$ soil, $13.14 \%$ in the second one, respectively. 
Table 4. Effect of different treatments on exchangeable cations after maize and barley in the first and second seasons (summer 2017 and winter 2017/2018)

\begin{tabular}{|c|c|c|c|c|c|c|c|c|c|c|c|c|c|c|}
\hline \multirow{3}{*}{$\begin{array}{l}\text { Application } \\
\text { depth } \\
\text { cm }\end{array}$} & \multirow{3}{*}{$\begin{array}{l}\text { Nitrogen } \\
\text { fertilizer }\end{array}$} & \multirow{3}{*}{$\begin{array}{c}\text { Compost } \\
\text { rates } \\
\left(\text { ton fed }^{-1}\right)\end{array}$} & \multicolumn{6}{|c|}{ Maize (first season, summer 2017) } & \multicolumn{6}{|c|}{ Barley (second season, winter 2017/2018) } \\
\hline & & & \multicolumn{4}{|c|}{$\begin{array}{c}\text { Exchangeable cations, } \\
\text { meq } / 100 \mathrm{~g} \text { soil }\end{array}$} & \multirow{2}{*}{$\begin{array}{c}\text { CEC, } \\
\mathrm{meq} / 100 \mathrm{~g} \\
\text { soil }\end{array}$} & \multirow{2}{*}{$\begin{array}{c}\text { ESP, } \\
\%\end{array}$} & \multicolumn{4}{|c|}{$\begin{array}{c}\text { Exchangeable cations, } \\
\text { meq } / 100 \mathrm{~g} \text { soil }\end{array}$} & \multirow{2}{*}{$\begin{array}{c}\mathrm{CEC}, \\
\mathrm{meq} / 100 \mathrm{~g} \\
\text { soil }\end{array}$} & \multirow{2}{*}{ ESP, } \\
\hline & & & $\mathbf{C a}$ & $\mathrm{Mg}$ & $\mathrm{Na}$ & $\mathrm{K}$ & & & $\mathbf{C a}$ & $\mathbf{M g}$ & $\mathrm{Na}$ & $\mathrm{K}$ & & \\
\hline \multirow{16}{*}{ D1 } & \multirow{4}{*}{1} & C1 & 21.22 & 14.82 & 5.94 & 0.64 & 42.62 & 13.94 & 21.23 & 14.83 & 5.93 & 0.65 & 42.64 & 13.91 \\
\hline & & $\mathrm{C} 2$ & 21.24 & 14.84 & 5.90 & 0.71 & 42.69 & 13.82 & 21.27 & 14.87 & 5.89 & 0.72 & 42.75 & 13.78 \\
\hline & & C3 & 21.29 & 14.90 & 5.88 & 0.82 & 42.89 & 13.71 & 21.31 & 14.92 & 5.86 & 0.84 & 42.93 & 13.65 \\
\hline & & & 21.35 & 15.04 & 5.84 & 0.88 & 43.11 & 13.55 & 21.38 & 15.07 & 5.83 & 0.89 & 43.17 & 13.50 \\
\hline & \multirow{4}{*}{ N2 } & & 21.24 & 14.85 & 5.90 & 0.66 & 42.65 & 13.83 & 21.26 & 14.86 & 5.88 & 0.67 & 42.67 & 13.78 \\
\hline & & $\mathrm{C} 2$ & 21.32 & 14.96 & 5.81 & 0.73 & 42.82 & 13.57 & 21.35 & 14.99 & 5.80 & 0.74 & 42.88 & 13.53 \\
\hline & & C3 & 21.35 & 15.00 & 5.79 & 0.80 & 42.94 & 13.48 & 21.37 & 15.02 & 5.77 & 0.81 & 42.97 & 13.43 \\
\hline & & C4 & 21.45 & 15.11 & 5.76 & 0.90 & 43.22 & 13.33 & 21.48 & 15.14 & 5.75 & 0.91 & 43.28 & 13.29 \\
\hline & & C & 21.33 & 14.94 & 5.86 & 0.66 & 42.79 & 13.69 & 21.36 & 14.98 & 5.85 & 0.68 & 42.87 & 13.65 \\
\hline & & C2 & 21.38 & 15.09 & 5.81 & 0.78 & 43.06 & 13.49 & 21.40 & 15.12 & 5.79 & 0.79 & 43.10 & 13.43 \\
\hline & & C3 & 21.42 & 15.12 & 5.77 & 0.86 & 43.17 & 13.37 & 21.44 & 15.15 & 5.75 & 0.87 & 43.21 & 13.31 \\
\hline & & C4 & 21.46 & 15.13 & 5.71 & 0.91 & 43.21 & 13.21 & 21.48 & 15.16 & 5.69 & 0.92 & 43.25 & 13.16 \\
\hline & \multirow{4}{*}{ N4 } & & 21.37 & 14.97 & 5.82 & 0.70 & 42.86 & 13.58 & 21.40 & 15.01 & 5.82 & 0.72 & 42.95 & 13.55 \\
\hline & & $\mathrm{C} 2$ & 21.44 & 15.03 & 5.74 & 0.81 & 43.02 & 13.34 & 21.48 & 15.08 & 5.74 & 0.83 & 43.13 & 13.31 \\
\hline & & C3 & 21.54 & 15.11 & 5.62 & 0.89 & 43.16 & 13.02 & 21.58 & 15.16 & 5.62 & 0.91 & 43.27 & 12.99 \\
\hline & & $\mathrm{C} 4$ & 21.60 & 15.14 & 5.57 & 0.97 & 43.28 & 12.87 & 21.63 & 15.18 & 5.56 & 0.98 & 43.35 & 12.83 \\
\hline \multirow{16}{*}{ D2 } & \multirow{4}{*}{ N1 } & & 21.24 & 14.84 & 5.93 & 0.71 & 42.72 & 13.88 & 21.26 & 14.86 & 5.92 & 0.72 & 42.76 & 13.84 \\
\hline & & $\mathrm{C} 2$ & 21.29 & 14.89 & 5.88 & 0.73 & 42.79 & 13.74 & 21.31 & 14.91 & 5.86 & 0.75 & 42.83 & 13.68 \\
\hline & & $\mathrm{C} 3$ & 21.48 & 14.98 & 5.72 & 0.79 & 42.97 & 13.31 & 21.50 & 15.00 & 5.70 & 0.81 & 43.01 & 13.25 \\
\hline & & & 21.64 & 15.09 & 5.69 & 0.84 & 43.26 & 13.15 & 21.66 & 15.11 & 5.67 & 0.86 & 43.30 & 13.09 \\
\hline & & C1 & 21.29 & 14.90 & 5.87 & 0.72 & 42.78 & 13.72 & 21.31 & 14.92 & 5.85 & 0.74 & 42.82 & 13.66 \\
\hline & & C2 & 21.38 & 14.95 & 5.80 & 0.76 & 42.89 & 13.52 & 21.40 & 14.97 & 5.78 & 0.78 & 42.93 & 13.46 \\
\hline & & C3 & 21.39 & 14.98 & 5.76 & 0.85 & 42.98 & 13.40 & 21.41 & 15.00 & 5.74 & 0.87 & 43.02 & 13.34 \\
\hline & & & 21.56 & 15.10 & 5.70 & 0.94 & 43.30 & 13.16 & 21.58 & 15.12 & 5.68 & 0.96 & 43.34 & 13.11 \\
\hline & & C1 & 21.38 & 14.99 & 5.78 & 0.74 & 42.89 & 13.48 & 21.40 & 15.02 & 5.76 & 0.75 & 42.93 & 13.42 \\
\hline & & & 21.55 & 15.07 & 5.71 & 0.81 & 43.14 & 13.24 & 21.57 & 15.10 & 5.69 & 0.82 & 43.18 & 13.18 \\
\hline & INS & C3 & 21.58 & 15.09 & 5.67 & 0.88 & 43.22 & 13.12 & 21.60 & 15.12 & 5.65 & 0.89 & 43.26 & 13.06 \\
\hline & & & 21.62 & 15.13 & 5.61 & 0.92 & 43.28 & 12.96 & 21.64 & 15.16 & 5.59 & 0.93 & 43.32 & 12.90 \\
\hline & & $C$ & 21.54 & 15.02 & 5.75 & 0.78 & 43.09 & 13.34 & 21.56 & 15.05 & 5.73 & 0.79 & 43.13 & 13.29 \\
\hline & & $\mathrm{C} 2$ & 21.57 & 15.06 & 5.72 & 0.80 & 43.15 & 13.26 & 21.59 & 15.09 & 5.70 & 0.81 & 43.19 & 13.20 \\
\hline & 104 & C3 & 21.61 & 15.18 & 5.66 & 0.85 & 43.30 & 13.07 & 21.63 & 15.21 & 5.64 & 0.86 & 43.34 & 13.01 \\
\hline & & C4 & 21.66 & 15.21 & 5.62 & 0.89 & 43.38 & 12.96 & 21.68 & 15.24 & 5.60 & 0.90 & 43.42 & 12.90 \\
\hline A Applica- & D1 (s & urface) & 21.38 & 15.00 & 5.80 & 0.80 & 42.97 & 13.49 & 21.40 & 15.03 & 5.78 & 0.81 & 43.03 & 13.44 \\
\hline tion depth & D2 (3 & $30 \mathrm{~cm})$ & 21.49 & 15.03 & 5.74 & 0.81 & 43.07 & 13.33 & 21.51 & 15.06 & 5.72 & 0.83 & 43.11 & 13.27 \\
\hline & & test & ** & ** & ** & ** & ** & $\star \star *$ & $* *$ & $\star \star *$ & ** & $\star \star *$ & ** & $\star *$ \\
\hline & & $(0 \%)$ & 21.34 & 14.93 & 5.85 & 0.77 & 42.88 & 13.64 & 21.37 & 14.95 & 5.83 & 0.78 & 42.92 & 13.59 \\
\hline & N2 ( & (50\%) & 21.37 & 14.98 & 5.80 & 0.80 & 42.95 & 13.50 & 21.40 & 15.00 & 5.78 & 0.81 & 42.99 & 13.45 \\
\hline fert & & (75\%) & 21.47 & 15.07 & 5.74 & 0.82 & 43.10 & 13.32 & 21.49 & 15.10 & 5.72 & 0.83 & 43.14 & 13.26 \\
\hline & & $100 \%)$ & 21.54 & 15.09 & 5.69 & 0.84 & 43.16 & 13.18 & 21.57 & 15.13 & 5.68 & 0.85 & 43.22 & 13.14 \\
\hline & & & ${ }^{* *}$ & & ** & $\star \star *$ & ** & $* *$ & ** & $* *$ & $\star *$ & $\star *$ & $\star *$ & $\star *$ \\
\hline & & $1(0)$ & 21.33 & 14.92 & 5.86 & 0.70 & 42.80 & 13.68 & 21.35 & 14.94 & 5.84 & 0.72 & 42.85 & 13.64 \\
\hline & C2 & (2.5) & 21.40 & 14.99 & 5.80 & 0.77 & 42.95 & 13.50 & 21.42 & 15.02 & 5.78 & 0.78 & 43.00 & 13.45 \\
\hline & & כ) (J) & 21.46 & 15.05 & 5.73 & 0.84 & 43.08 & 13.31 & 21.48 & 15.07 & 5.72 & 0.86 & 43.13 & 13.26 \\
\hline & & (7.5) & 21.54 & 15.12 & 5.69 & 0.91 & 43.26 & 13.15 & 21.57 & 15.15 & 5.67 & 0.92 & 43.30 & 13.10 \\
\hline & & test & $* *$ & ** & $* *$ & $* *$ & ** & $* *$ & ** & $* *$ & ** & $* *$ & $\star *$ & $* *$ \\
\hline
\end{tabular}


Also, the results reveal that the Ex. $\mathrm{Na}$ and ESP values were significantly decreased with increasing compost rates, where the lowest values were obtained by the addition of 7.5 ton compost fed ${ }^{-1}$. The decreases of Ex. Na were reached to 5.69 and $5.67 \mathrm{meq} / 100 \mathrm{~g}$ soil, and the decreases of ESP were reached to 13.15 and $13.10 \%$ as a mean values in the first and second seasons, respectively. Similar conclusion was obtained by El-Maddah et al (2012).

III- Effect of different treatments on soil macronutrients and $\mathrm{C} / \mathrm{N}$ ratio.

\section{1- Soil macronutrients}

Results in Table (5) indicate that total macronutrients of soil (N, P and K) were increased with all treatments for the two soil depths $(10$ and $30 \mathrm{~cm})$ at the end of the two growing seasons. The highest values of total soil $\mathrm{N}, \mathrm{P}$ and $\mathrm{K}$ were recorded by the addition of 7.5 ton compost fed ${ }^{-1}$ filled in $30 \mathrm{~cm}$ mole depth with 100 $\%$ recommended dose of nitrogen fertilizer for each crop, where the increases were reached to 0.156 , 0.053 and $0.349 \%$ in the first season and $0.158,0.056$ and $0.360 \%$ in the second one for the total soil N, P and $\mathrm{K}$, respectively.

Data in Table (5) indicate that total soil N, P and $\mathrm{K}$ were significantly increased by increasing application depth, where the use of $30 \mathrm{~cm}$ mole depth was more effective on increasing total soil N, P and $\mathrm{K}$ than $10 \mathrm{~cm}$ surface depth. The increases of them reached to $0.148,0.042$ and $0.335 \%$ in the first season, while in the second one reached to $0.150,0.045$ and $0.345 \%$, respectively as a mean values.

Concerning the application of nitrogen fertilizer rates, the results reveal that total soil $\mathrm{N}, \mathrm{P}$ and $\mathrm{K}$ were significantly increased by using $100 \%$ recommended dose of nitrogen fertilizer for each crop. It can be noticed that, the increases of total soil $\mathrm{N}$, $\mathrm{P}$ and $\mathrm{K}$ reached to $0.151,0.046$ and $0.339 \%$ in the first season, while in the second one reached to $0.152,0.048$ and $0.348 \%$, respectively. Similar conclusions were obtained by Zhong et al (2014).

Concerning the application of compost rates, It can be noticed that increasing compost rates addition led to significant increases in total soil $\mathrm{N}, \mathrm{P}$ and $\mathrm{K}$. The highest values were obtained by the application of 7.5 ton compost fed ${ }^{-1}$, where they increase to 0.151 , 0.047 and $0.341 \%$ in the first season, and 0.153 , 0.050 and $0.354 \%$ in the second one, respectively as a mean values. These results suggest that it may be practical to apply these compost rates to soils to increase NPK concentrations in the soil and thereby enhance its availability to plants. These results are in agreement with those reported by El-Maddah et al (2012) and Gayathri \& Srinivasamurthy (2016).

\section{2- Organic carbon (O.C) and $\mathrm{C} / \mathrm{N}$ ratio}

Data in Table (5) show that the soil organic carbon (O.C) and $\mathrm{C} / \mathrm{N}$ ratio were significantly increased with all different treatments at the end of the two seasons. The highest values of (O.C) and $\mathrm{C} / \mathrm{N}$ ratio were obtained by using 7.5 ton compost fed ${ }^{-1}$ in $30 \mathrm{~cm}$ mole depth with $100 \%$ recommended dose of nitrogen fertilizer for each crop, where they increased to $1.682 \%$ and 10.78 in the first season, and $1.654 \%$ and 10.47 in the second one, respectively. This may be due to the increase in total $\mathrm{N}$ is higher than that in O.C., narrower $\mathrm{C} / \mathrm{N}$ ratio of the treated soils were obtained indicating the mineralization of organic nitrogen compounds and hence the possibility to save and provide available forms of $\mathrm{N}$ to growing plants. Similar conclusions were obtained by Saraiya et al (2005), Elhady \& Abo-Sedera (2006) and Meena et al (2015).

The results clearly show that, increasing the application depth led to significantly increases in (O.C) and $\mathrm{C} / \mathrm{N}$ ratio. It can be noticed that the use of 30 $\mathrm{cm}$ mole depth was more effective than $10 \mathrm{~cm}$ surface depth on increasing (O.C) and $\mathrm{C} / \mathrm{N}$ ratio of the soil, where the increases were reached to $1.583 \%$ and 10.71 in the first season, and $1.556 \%$ and 10.40 in the second one, respectively as a mean values. Similar results were obtained by El-Sodany et al (2016)

Concerning the addition of nitrogen fertilizer rates, the results show that the values of (O.C) and $\mathrm{C} / \mathrm{N}$ ratio of the soil were significantly increased by increasing nitrogen fertilizer rates, where the highest values were recorded by using $100 \%$ recommended dose of nitrogen fertilizer for each crop. The increases of (O.C) and $\mathrm{C} / \mathrm{N}$ ratio of the soil were reached to $1.615 \%$ and 10.72 in the first season, while in the second one reached to $1.584 \%$ and 10.41 , respectively as a mean values. Similar results were recorded by Wapa \& Oyetola (2014) and Abd-Allah (2014).

Also, the application of compost rates led to significantly increases of O.C and $\mathrm{C} / \mathrm{N}$ ratio at the end of the two seasons. The highest values of O.C and $\mathrm{C} / \mathrm{N}$ ratio were recorded by the application of 7.5 ton compost fed $^{-1}$, where its increases were $1.618 \%$ and 10.73 in the first season, and $1.592 \%$ and 10.42 in the second one, respectively as a mean values. Similar results were recorded by Guo et al (2016) and Agegnehu et al (2016). 
Table 5. Effect of different treatments on soil macronutrients and $\mathrm{C} / \mathrm{N}$ ratio after maize and barley in the first and second seasons (summer 2017 and winter 2017/2018)

\begin{tabular}{|c|c|c|c|c|c|c|c|c|c|c|c|c|}
\hline \multirow{3}{*}{$\begin{array}{l}\text { Application } \\
\text { depth } \mathbf{c m}\end{array}$} & \multirow{3}{*}{$\begin{array}{l}\text { Nitrogen } \\
\text { fertilizer }\end{array}$} & \multirow{3}{*}{$\begin{array}{c}\text { Compost } \\
\text { rates } \\
\left(\text { ton }^{-1} \text { fed }^{-1}\right)\end{array}$} & \multicolumn{5}{|c|}{ Maize (first season, summer 2017) } & \multicolumn{5}{|c|}{$\begin{array}{l}\text { Barley (second season, winter } \\
2017 / 2018 \text { ). }\end{array}$} \\
\hline & & & \multicolumn{3}{|c|}{$\begin{array}{c}\text { Total macronutrients, } \\
\%\end{array}$} & \multirow{2}{*}{$\begin{array}{c}\text { Organic } \\
\text { carbon, } \\
\%\end{array}$} & \multirow{2}{*}{$\begin{array}{l}\mathrm{C} / \mathrm{N} \\
\text { ratio }\end{array}$} & \multicolumn{3}{|c|}{$\begin{array}{c}\text { Total macronutrients, } \\
\%\end{array}$} & \multirow{2}{*}{$\begin{array}{c}\text { Organic } \\
\text { carbon, } \\
\%\end{array}$} & \multirow{2}{*}{$\begin{array}{l}\mathrm{C} / \mathrm{N} \\
\text { ratio }\end{array}$} \\
\hline & & & $\mathbf{N}$ & $\mathbf{P}$ & $\mathbf{K}$ & & & $\mathbf{N}$ & $\mathbf{P}$ & $\mathbf{K}$ & & \\
\hline \multirow{16}{*}{ D1 } & \multirow{4}{*}{ N1 } & C1 & 0.138 & 0.032 & 0.319 & 1.467 & 10.63 & 0.142 & 0.035 & 0.328 & 1.465 & 10.32 \\
\hline & & $\mathrm{C} 2$ & 0.140 & 0.034 & 0.323 & 1.491 & 10.65 & 0.144 & 0.038 & 0.335 & 1.489 & 10.34 \\
\hline & & C3 & 0.142 & 0.035 & 0.329 & 1.514 & 10.66 & 0.145 & 0.040 & 0.339 & 1.501 & 10.35 \\
\hline & & $\mathrm{C} 4$ & 0.145 & 0.037 & 0.334 & 1.549 & 10.68 & 0.147 & 0.041 & 0.347 & 1.524 & 10.37 \\
\hline & \multirow{4}{*}{ N2 } & C1 & 0.141 & 0.034 & 0.324 & 1.500 & 10.64 & 0.143 & 0.037 & 0.332 & 1.477 & 10.33 \\
\hline & & $\mathrm{C} 2$ & 0.145 & 0.038 & 0.328 & 1.547 & 10.67 & 0.146 & 0.040 & 0.339 & 1.513 & 10.36 \\
\hline & & $\mathrm{C} 3$ & 0.146 & 0.041 & 0.332 & 1.561 & 10.69 & 0.149 & 0.043 & 0.343 & 1.547 & 10.38 \\
\hline & & $\mathrm{C} 4$ & 0.148 & 0.047 & 0.335 & 1.585 & 10.71 & 0.150 & 0.049 & 0.351 & 1.559 & 10.39 \\
\hline & \multirow{4}{*}{ N3 } & C1 & 0.143 & 0.037 & 0.327 & 1.523 & 10.65 & 0.144 & 0.039 & 0.334 & 1.489 & 10.34 \\
\hline & & $\mathrm{C} 2$ & 0.147 & 0.040 & 0.332 & 1.571 & 10.69 & 0.149 & 0.042 & 0.341 & 1.545 & 10.37 \\
\hline & & C3 & 0.149 & 0.044 & 0.336 & 1.594 & 10.70 & 0.151 & 0.047 & 0.348 & 1.569 & 10.39 \\
\hline & & C4 & 0.152 & 0.050 & 0.341 & 1.629 & 10.72 & 0.154 & 0.052 & 0.354 & 1.605 & 10.42 \\
\hline & \multirow{4}{*}{ N4 } & C1 & 0.145 & 0.039 & 0.329 & 1.546 & 10.66 & 0.146 & 0.041 & 0.335 & .511 & 10.35 \\
\hline & & $\mathrm{C} 2$ & 0.148 & 0.042 & 0.334 & 1.584 & 10.70 & 0.149 & 0.044 & 0.344 & 1.547 & 10.38 \\
\hline & & C3 & 0.151 & 0.045 & 0.338 & 1.617 & 10.71 & 0.153 & 0.047 & 0.350 & 1.593 & 10.41 \\
\hline & & $\mathrm{C} 4$ & 0.155 & 0.051 & 0.346 & 1.663 & 10.73 & 0.157 & 0.053 & 0.358 & .639 & 10.44 \\
\hline \multirow{16}{*}{ D2 } & \multirow{4}{*}{$\mathrm{N} 1$} & C1 & 0.139 & 0.033 & 0.321 & 1.479 & 10.64 & 0.143 & 0.036 & 0.331 & 1.477 & 10.33 \\
\hline & & $\mathrm{C} 2$ & 0.142 & 0.036 & 0.325 & 1.515 & 10.67 & 0.145 & 0.039 & 0.338 & 1.501 & 10.35 \\
\hline & & C3 & 0.144 & 0.037 & 0.331 & 1.538 & 10.68 & 0.146 & 0.041 & 0.342 & 1.514 & 10.37 \\
\hline & & $\mathrm{C} 4$ & 0.145 & 0.038 & 0.336 & 1.552 & 10.70 & 0.148 & 0.042 & 0.349 & 1.536 & 10.38 \\
\hline & \multirow{4}{*}{ N2 } & C1 & 0.142 & 0.036 & 0.326 & 1.514 & 10.66 & 0.145 & 0.038 & 0.335 & 1.501 & 10.35 \\
\hline & & C2 & 0.146 & 0.039 & 0.331 & 1.561 & 10.69 & 0.148 & 0.041 & 0.342 & 1.536 & 10.38 \\
\hline & & $\mathrm{C} 3$ & 0.149 & 0.042 & 0.337 & 1.594 & 10.70 & 0.151 & 0.045 & 0.347 & 1.570 & 10.40 \\
\hline & & C4 & 0.151 & 0.049 & 0.342 & 1.619 & 10.72 & 0.152 & 0.052 & 0.355 & 1.585 & 10.43 \\
\hline & & C1 & 0.145 & 0.039 & 0.329 & 1.549 & 10.68 & 0.146 & 0.040 & 0.337 & 1.514 & 10.37 \\
\hline & $N / 3$ & $\mathrm{C} 2$ & 0.148 & 0.041 & 0.335 & 1.585 & 10.71 & 0.149 & 0.044 & 0.343 & 1.550 & 10.40 \\
\hline & INO & C3 & 0.153 & 0.045 & 0.340 & 1.642 & 10.73 & 0.154 & 0.049 & 0.349 & 1.606 & 10.43 \\
\hline & & $\mathrm{C} 4$ & 0.155 & 0.052 & 0.344 & 1.668 & 10.76 & 0.156 & 0.056 & 0.357 & 1.630 & 10.45 \\
\hline & & C1 & 0.147 & 0.042 & 0.331 & 1.573 & 10.70 & 0.148 & 0.043 & 0.339 & 1.536 & 10.38 \\
\hline & & $\mathrm{C} 2$ & 0.150 & 0.045 & 0.339 & 1.608 & 10.72 & 0.151 & 0.047 & 0.347 & 1.573 & 10.42 \\
\hline & $\mathrm{N} 4$ & C3 & 0.153 & 0.049 & 0.343 & 1.645 & 10.75 & 0.155 & 0.051 & 0.352 & 1.620 & 10.45 \\
\hline & & $\mathrm{C} 4$ & 0.156 & 0.053 & 0.349 & 1.682 & 10.78 & 0.158 & 0.056 & 0.360 & 1.654 & 10.47 \\
\hline A & D1 (su & urface) & 0.146 & 0.040 & 0.332 & 1.559 & 10.68 & 0.148 & 0.043 & 0.342 & 1.536 & 10.37 \\
\hline Application & D2 (3 & $30 \mathrm{~cm})$ & 0.148 & 0.042 & 0.335 & 1.583 & 10.71 & 0.150 & 0.045 & 0.345 & 1.556 & 10.40 \\
\hline depth cm & & test & & ${ }^{* *}$ & ** & ** & $* *$ & ** & $* *$ & $\star *$ & $* *$ & $* *$ \\
\hline & N1 & $(0 \%)$ & 0.142 & 0.035 & 0.327 & 1.513 & 10.66 & 0.145 & 0.039 & 0.339 & 1.501 & 10.35 \\
\hline & & (50\%) & 0.146 & 0.041 & 0.332 & 1.560 & 10.69 & 0.148 & 0.043 & 0.343 & 1.536 & 10.38 \\
\hline Nitrogen & N3 & (75\%) & 0.149 & 0.044 & 0.336 & 1.595 & 10.71 & 0.150 & 0.046 & 0.345 & 1.564 & 10.40 \\
\hline fertilizer & N4 (1 & $100 \%)$ & 0.151 & 0.046 & 0.339 & 1.615 & 10.72 & 0.152 & 0.048 & 0.348 & 1.584 & 10.41 \\
\hline & & test & & ** & ** & ** & * & ** & $* *$ & ** & ** & ** \\
\hline & & $1(0)$ & 0.143 & 0.037 & 0.326 & 1.519 & 10.66 & 0.145 & 0.039 & 0.334 & 1.496 & 10.35 \\
\hline & & (2.5) & 0.146 & 0.039 & 0.331 & 1.558 & 10.69 & 0.148 & 0.042 & 0.341 & 1.532 & 10.38 \\
\hline & & & 0.148 & 0.042 & 0.336 & 1.588 & 10.70 & 0.151 & 0.045 & 0.346 & 1.565 & 10.40 \\
\hline & C4 & (7.5) & 0.151 & 0.047 & 0.341 & 1.618 & 10.73 & 0.153 & 0.050 & 0.354 & 1.592 & 10.42 \\
\hline & & & 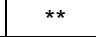 & $\star \star *$ & $\star \star *$ & $\star *$ & 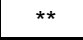 & ** & $\star *$ & $* *$ & $\star *$ & $\star \star \star$ \\
\hline
\end{tabular}




\section{IV- Economical analysis}

Table (6) show the inputs production items of the experiments through the two growing seasons under study (summer season 2017 and winter season 2017/2018). The obtained results in Fig. (1) indicated that the highest net income value (16809.80 L.E fed ${ }^{-1}$ ) was incorporated with the application of 5.0 ton compost $\mathrm{fed}^{-1}$ in $30 \mathrm{~cm}$ mole depth with $100 \%$ recommended dose of nitrogen fertilizer for each crop, which was the best treatment and should be recommended due to relative high net income comparing to the other treatments.
This may be due to this treatment was recorded the highest values of yield in the first and second seasons, consequently high net profit. It can be seen that it is better from the economic view to increase the mole depth up to $30 \mathrm{~cm}$ to increase the net profit. These results are in line with those reported by Amer (2016).

Finally, it could be concluded that under clay loam soil conditions, the use of compost at the rate 5 ton fed $^{-1}$ filled moles at $30 \mathrm{~cm}$ depth with nitrogen fertilizer at the rate $100 \%$ of the recommended dose have pronounced effect on improving most of the soil chemical properties.

Table 6. Input production items and output of the experiments through the two growing seasons under study (summer season 2017 and winter season 2017/2018)

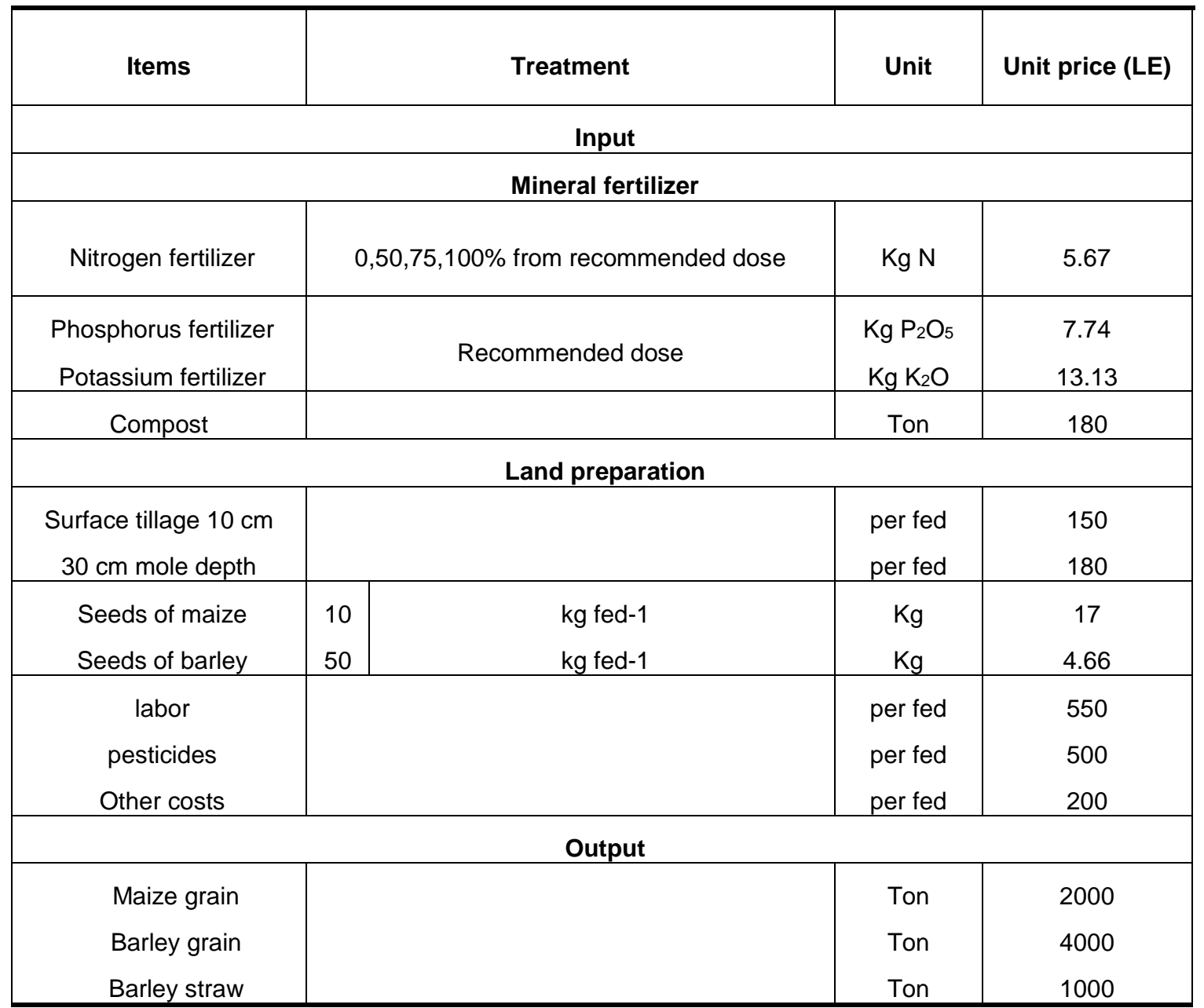




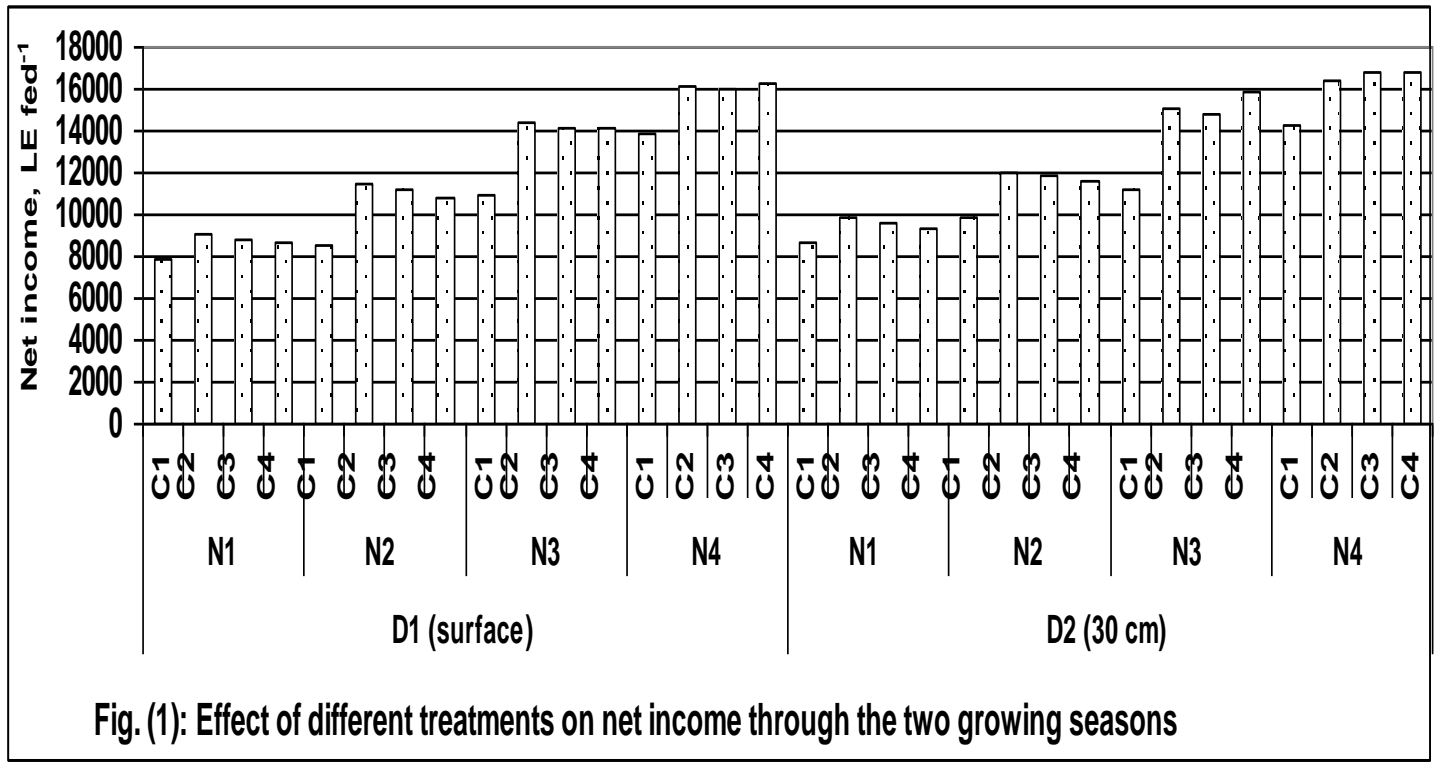

\section{REFERENCES}

Abd-Allah Y.A.M. 2014. Effect of plant residues as soil amendments on soil properties and it's productivity. Ph.D. Thesis. Depart. Of Environ. Agric. Sci. Institute of Environmental studied and research, Ain Shams Univ. Egypt.

Abou El-Soud M.A., Ghazy M.A., Shams El-Din H.A. and El-Abaseri M.A. 1996. Sand-filled mole drain installation for improvement of soil properties. Misr, J. Ag. Eng., Cairo Univ. Egypt, Irr. Conf. 3-4 April. pp. 88-99.

Agegnehu G., Nelson P.N. and Bird M.I. 2016. Crop yield, plant nutrient uptake and soil physicochemical properties under organic soil amendments and nitrogen fertilization on Nitisols. Soil \& Tillage Res. 1(60), 1-13.

Amer M.M. 2016. Effect of biochar, compost tea and magnetic iron ore application on some soil properties and productivity of some field crops under saline soils conditions at North Nile Delta. Egypt. J. Soil Sci. 56(1), 169-185.

Black C.A. 1965. Methods of Soil Analysis. Parts 1 and 2. Amer. Soc. Agron. No. 9, Madison, Wisconsin USA.

Convertini G., Ferri D.., Montemurro F. and Maiorana M. 2004. Effects of municipal solid waste compost on soils cropped with tomato and sunflower in rotation with durum wheat. Proc. of the $13^{\text {th }}$ International Soil Conservation Organization Conference, 1-4.
Eghball B., Ginting D. and Gilley J.E. 2004. Residual effects of manure and compost applications on corn production and soil properties. Agron. J. 96, 442-447.

El-Hady O.A. and Abo-Sedera S.A. 2006. Conditioning effect of composts and acrylamide hydrogels on a sandy calcareous soil. II-Physicobio-chemical Properties of the Soil. Int. J. Agri. Biol. 8(6), 876-884.

El-Maddah E.I. and El-Sodany M.El-D. 2003. Effect of deep plowing on improving some soil physical and chimical properties of compacted clayey soils. Minufiya J. Agric. Res. 28(4), 1201-1222.

El-Maddah E.I., El-Sodany M.EI-D. and El-Attar M.A. 2007. Effect of crop residues filled moles on some properties and productivity of soils. J. Agric. Sci. Mansoura Univ., Mansoura, Egypt, 32(12), 10703-10732.

El-Maddah E.I., El-Sodany M.EI-D. and Mahmoud A.A. 2012. Effect of different tillage systems and soil conditioners on some soil chemical properties and status of nutrients. Egypt. J. of Appl. Sci., 27(12), 968-995.

El-Maddah E.I., El-Sodany M.El-D. and Mahmoud A.A. 2015. Evaluation of Some Soil Conditioners by Tetra-Factorial Computer Model and Their Effects on Some Soil Chemical Properties and its Productivity. Int. J. Chem. Tech Res., 8(9), 54-83. 
El-Sabry W.S., Abo El-Soud M.A., Abo-Soliman M.S.M. and El-Abaseri M.A. 1992. Effect of sandy back filled mole on some physical and chemical properties and productivity of clayey compacted soil. J. Agric. Sci. Mansoura Univ., Mansoura, Egypt, 17(8), 2790-2797.

El-Shouny M.M. 2006. The effect of some soil amendments on soil properties and wheat production in salt affected soils. Minufiya J. Agric. Res., 31(4), 1105-1117.

El-Sodany M.El-D., El-Maddah E.I. and ElSherief M.A.B. 2007. Effect of organic residues as soil amendments on some soil chemical properties and productivity. Arab Conference of Soil and Water Management for Sustainable Agricultural Development, 10-11 April 2007, Soils Department, Fac. of Agric., Mansoura Univ., Mansoura, Egypt, pp. 355383.

El-Sodany M.EI-D. and El-Maddah E.I. 2009. Effect of organic matter and inorganic phosphorus application on some chemical properties and soil phosphorus fractions. J. Agric. Sci. Mansoura Univ., Mansoura, Egypt 34(3), 2357-2380.

El-Sodany M.EI-D., El-Maddah E.I., Samia M.S. El-Kalawy and El-Sherief M.A.B. 2016. Effect of compost rates at different depths on some chemical properties and productivity of soils. J. Soil Sci. and Agric. Eng., Mansoura Univ., Mansoura, Egypt, 7(7), 447-459.

Gayathri B and Srinivasamurthy C.A. 2016. Effect of different levels and sources of humic acid extracted from organic wastes on soil properties, growth, yield and nutrient uptake by maize. Mysore J. Agric. Sci. 50(2), 463-468.

Guo L., Wu G., Li Y., Li C., Liu W., Meng J., Liu H., Yu X. and Jiang G. 2016. Effects of cattle manure compost combined with chemical fertilizer on topsoil organic matter, bulk density and earthworm activity in a wheat-maize rotation system in Eastern China. Soil \& Tillage. Res. 15(6), 140-147.

Hesse P.P. 1971. A Text Book of Soil Chemical Analysis-John- Murray (pupils.), London Great Britan.

Meena B.P., Ashok K., Lal B., Sinha N.K., Tiwari P.K., Dotaniya M.L., Jat N.K. and Meena V.D. 2015. Soil microbial, chemical properties and crop productivity as affected by organic manure application in popcorn (Zea mays L. var. everta). African J. of Microbiology Res. 9(21), 1402-1408.

Mohammad A.M. and Battikhi A.M. 1997. Effect of sewage sludge on some soil properties and barley plant in Muwaqar area. Dirasat, 24(2), 204216.

Page A.L., Miller R.H. and Keeney D.R. 1982. Methods of Soil Analysis. Part 2. Chemical and Microbiological properties. Second Edition. Madison, Wisconsin, USA, 1184S.

Saraiya A.B., Tomar S.S. and Sharma S.K. 2005. Effect of crop residue and tillage practices on physico-chemical properties and yield of wheat grown after rice in Vertisols. Res. J. 39(1), 5763.

Sendecor G.W. and Cochran W.G. 1981. Statistical Methods. $7^{\text {th }}$ Ed. lowa State Univ. Press, Ames. lowa, USA, pp. 305-310.

Wapa J.M. and Oyetola S.O. 2014. Combining effects of nitrogen fertilizer and different organic manures on major chemical properties of Typic Ustipsament in North-East Nigeria. American Intern. J. of Biology, 2(2), 27-45.

Zhong H., Wang Q., Zhao X., Du Q., Zhao Y., Wang X., Jiang C., Zhao S., Cao M., Yu H. and Wang D. 2014. Effects of different nitrogen applications on soil physical, chemical properties and yield in maize (Zea mays L.). Agric. Sci., 5, 1440-1447. 


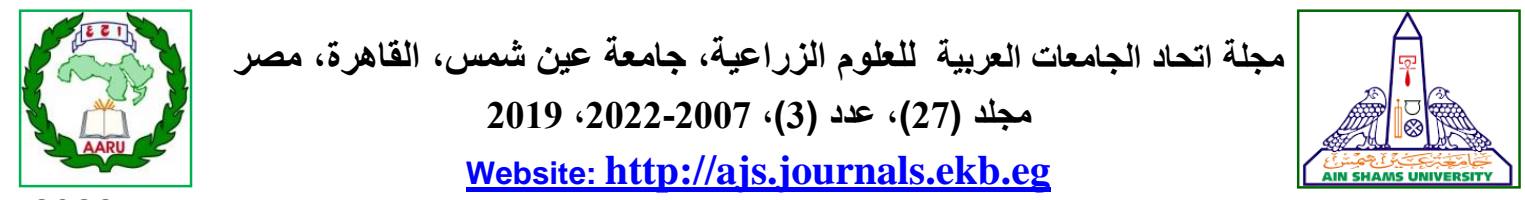

تأثير التسميد النتروجيني مع إضافة معدلات من الكمبوست في أعماق مختلفة علي بعض

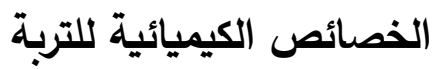

[161]

الحسيني إبراهيم المداح" - منصور الاسوقي السوداني - يسري أحمد محمود عبد الله

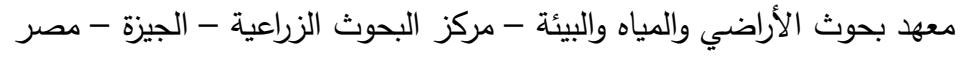

${ }^{*}$ Corresponding author: dr yosri@hotmail.com

Received 2 July, 2019

Accepted 5 August, 2019

والانيونات الذائبة بزيادة معدلات النتروجين والكمبوست

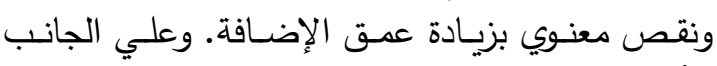

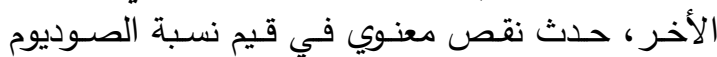

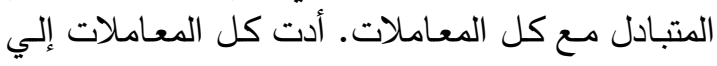

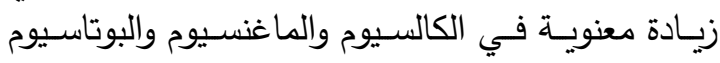

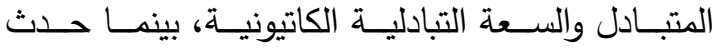
انخفاض معنوي في الصوديوم المتبادل والنسبة المئوية المبادية

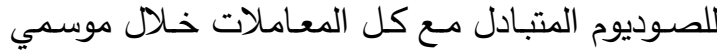

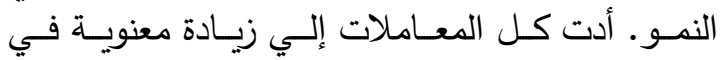

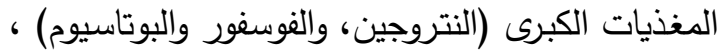

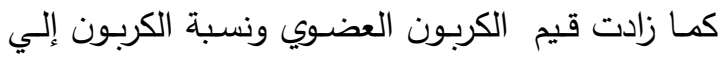

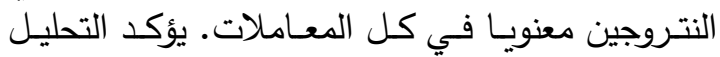

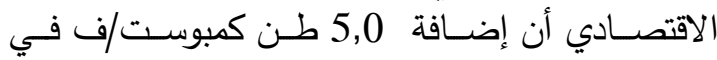

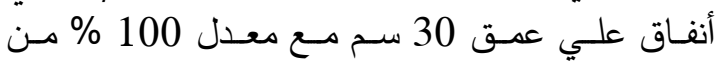

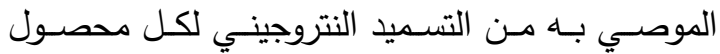

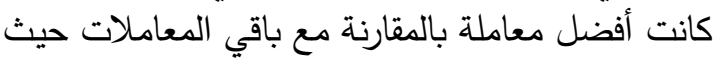
أعطت تحسنا واضحا في الخصائص الكيميائية للتربة باتِ

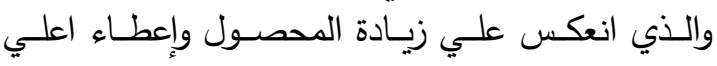
صافي دخل مزرعي (16809.80 جنية / فدان).

الكلمـات الدالـة: انفاق ، كمبوست، الخواص الكيميائية للتربة

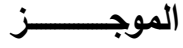

نفذت تجربتين حقليتين علي ارض طمييـة طينيـة خلال موسمين زراعيين، موسم صيفي 2017 باستخدام

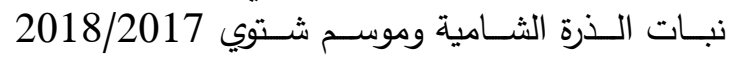

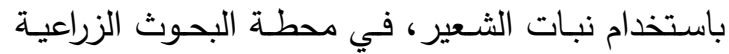

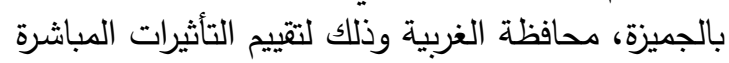
والمتبقية لإضـافة معدلات من الكمبوست علي علي سطح

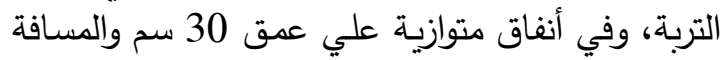

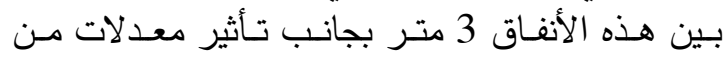

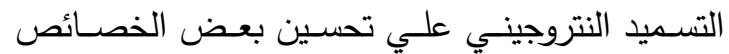

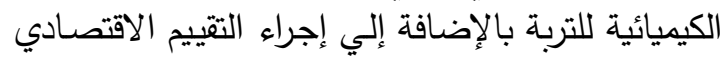

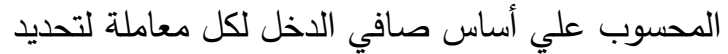

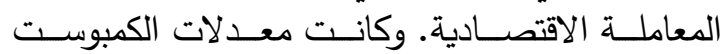

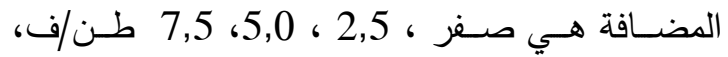
بينما معدلات إضافة النتروجين هي صفر ، 100 ، 50 ، 50 ، 75 ، 75 ،

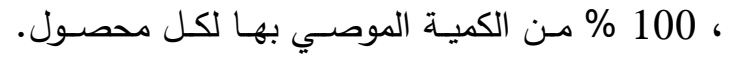
وكان تصميم التجربة قطاعات كاملـة العشوائية منثقة

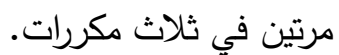

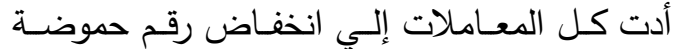

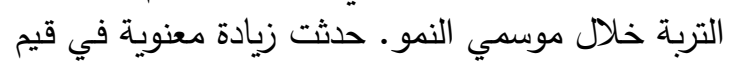

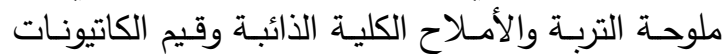

